\title{
Urban Stormwater and Sewerage Modelling: An Approach for Peak Runoff and Volume Assessment
}

\author{
Berhanu F. Alemaw, Nata T. Tafesse \\ Department of Geology, University of Botswana, Gaborone, Botswana \\ Email: alemaw@ub.ac.bw, bfalemaw@gmail.com, Nata.Tafesse@ub.ac.bw
}

How to cite this paper: Alemaw, B.F. and Tafesse, N.T. (2021) Urban Stormwater and Sewerage Modelling: An Approach for Peak Runoff and Volume Assessment. Journal of Water Resource and Protection, 13, 855-880. https://doi.org/10.4236/jwarp.2021.1311046

Received: October 21, 2021

Accepted: November 23, 2021

Published: November 26, 202

Copyright $\odot 2021$ by author(s) and Scientific Research Publishing Inc. This work is licensed under the Creative Commons Attribution International License (CC BY 4.0).

http://creativecommons.org/licenses/by/4.0/

\section{(c) (i) Open Access}

\begin{abstract}
In this study, an integrated approach for runoff estimation using the storm water management model (SWMM) was applied to undertake a stormwater and sewerage modelling in urban setting. The main objectives of the research and this manuscript include overload detection of sewer systems during extreme rainfall events with SWMM and to model and predict the relationship between precipitation parameters and overflooding of sewer collection system that includes emergency ponds to relieve flow from pump stations. The study takes into account monitored concurrent extreme rainfall event data and peak wet weather flows observed at outfall of collection system entering a wastewater treatment plant draining the urban centre. In the study SWMM was modified and adapted for the Tati and Ntshe confluence rivers draining the urban centre of Francistown in Northern Botswana. Landuse, soil, geological, drainage and sewerage network and imperviousness data sets were acquired and developed in GIS database. The runoff coefficient is found to range between 0.12 and 0.24 in the studied catchments. The calibrated model was able to predict the observed outputs with reasonable accuracy for calibration datasets of two peak flood events of 2016-Jan 12 and 2017-Feb 16 and verification flood events of 2016-Feb 05 and 2017-Feb 26. For six watersheds that drain the study area considered with a seventh entire collection system catchment area, we have evaluated the model performance using different criteria. We have found that correlation coefficients range from 0.539 to 0.813 and NSE ranges from $40.9 \%$ to $89.0 \%$, and RSR ranges from 0.330 to 0.812 for the calibration datasets. Whereas, for the verification dataset, the correlation coefficients range from 0.539 to 0.813 and NSE values range from $40.9 \%$ to $89.0 \%$, and RSR values range from 0.330 to 0.812 . Using the criteria adopted, the SWMM-simulated runoff values are in acceptable agreement with the observed hydrographs.
\end{abstract}




\section{Keywords}

SWMM, Peak Runoff, Runoff Volume, Sewerage System, Wastewater Treatment Plant, Calibration, Verification

\section{Introduction}

In order to effectively manage and control the nuisance of frequent flooding during rainy seasons, designing an efficient stormwater drainage system in urban settlements is a frequent challenge for engineers and urban planners. The present case study deals with calibration and validation of a SWMM model for providing a solution to stormwater management problems in an urbanized area with scarce observed data. Urbanization creates infrastructure problems and large modifications in the environment. One of these challenges is the increase in urban runoff, causing or exacerbating the urban disasters generated by the floods.

Furthermore, accelerated urbanization in different parts of the world has changed urban underlying surface, and the impervious proportion of areas has increased, resulting in lots of serious urban water problems [1]. High urbanization compounded with global climate change has also been the cause for increase in the frequency of extreme rainstorms [2]. Prudent management of urban collection systems is required to achieve sustainability in the water management and effective risk mitigation for urban settlements as illustrated in recent literature including [3] [4] [5] [6] [7].

In the late 1990s, as a best management practice, low impact development (LID) as a new concept was used in order to solve stormwater problems [8]. LIDs could control runoff from the source through infiltration, filtration, evapotranspiration and other natural hydrological processes, aiming to the reduction of runoff quantity and pollution, and the protection of the receiving water, which is different from traditional stormwater management [7].

In this study, evaluation of responses from urban watersheds is used as great interest for the urbanization flooding and modelling study in urban collection system. Various even-based hydrologic models are used to simulate rainfall-runoff processes in urban areas. Among these models, the Storm Water Management Model (SWMM) is a standard tool used widely. The present study was carried out to evaluate the use of the SWMM model on small sub catchments in an urban environment in a semi-arid setting. The focus was on the events calibration and on the understanding of the parameters involved in the simulation through a sensitivity analysis of them, based on observed field data from flow and rainfall monitoring.

Thus, the objectives of this research were to: 1 ) determine recommended model evaluation techniques (statistical and graphical); 2) review reported ranges of values that control rainfall-runoff processes and corresponding model perfor- 
mance ratings; 3) establish guidelines for consistent model evaluation ratings; and 4) research on the relationship between precipitation parameters and sewer system overflooding. All of these objectives focus on simulation of urban runoff collection system in terms of flood hydrographs, volumes and runoff coefficient under data scarce conditions.

The study objectives were achieved with a thorough review of relevant literature on model application and recommended model evaluation methods between the observed and model-simulated results. In order to qualitatively evaluate results interactive visualization of hydrographs was also used to determine if the observed and simulated hydrographs match in terms of flood peaks and time of occurrence of peaks, volumes, etc. Three quantitative criteria were further recommended for model evaluation and determine model performance namely: the Nash-Sutcliffe efficiency (NSE), and ratio of the root mean square error to the standard deviation of measured data (RSR) and the Pearson's correlation coefficient $(r)$. The following model evaluation performance ratings were established for each recommended statistic. In general, model simulation can be judged as satisfactory if $r>0.5$, NSE $>50 \%$ and RSR $<0.70$, constituent-specific performance ratings were determined based on uncertainty of measured data. Additional considerations related to model evaluation guidelines are also discussed. These considerations include: single-event simulation, quality and quantity of measured data, model calibration procedure, evaluation time step, and project scope and magnitude.

A case study illustrating the application of the model evaluation guidelines is also provided. Discrete event-based urban rainfall-runoff quantity models have been applied such as in Moriasi et al., [9], Zaghloul [10] and Williams [11]. The models illustrated in Williams [11] are those which are widely used by federal agencies including the Rational Method; TR-20, used by the U.S. Soil Conservation Service (SCS); HEC-1, used by the U.S. Army Corps of Engineers (USACE); Urban Flood Hydrograph Synthesis Model (G824), used by the USGS; SWMM, developed for the U.S. Environmental Protection Agency (EPA); and MINICAT, used by the National Weather Service, River Forecast Center (RFC). The models were calibrated for peak discharge on the recorded floods, and all except the Rational Method were calibrated for runoff volume. In the continuous modelling of stormwater hydraulics and quality, SWMM model was applied for the calibration and verification processes of urban areas as noted recently including Patil et al. [12] and Cambez et al.[13].

Models for low impact urban stormwater drainage are applied across different urban development and catchment treatment settings [14]. These include impact of Short Duration Intense Rainfall Events [15] [16] [17]; in Urban Drainage System Planning and Design [18] [19] [20] [21]; climate change impacts in urban environments [22] [23] [24] [25]. A comparison of the SWMM (Storm Water Management Model) and MIKE URBAN models were applied in recent study to simulate urban flooding and to enable design of efficient urban drainage system 
[26]. The SWMM was developed by U.S. EPA (Environmental Protection Agency) from 1969 to 1971 and has undergone several upgrades.

Automatic calibration of the U.S. EPA SWMM Model was achieved for a large urban catchment as noted in [27]. By combining SWMM with GIS and hydroinformatics, improvements in modelling of large spatial flood analysis of urban environments have been achieved in different cases. For instance, Kyung-sook and Ball [28] used information contained within a GIS database together with optimization techniques to infer spatially variable control parameters for utilization with a catchment modeling system such as the Storm-Water Management Model (SWMM). From the comparison of the new GIS-based and traditional calibration approaches, it was found that hydro informatics systems can be used effectively to evaluate catchment modeling system control parameters and to improve the accuracy and efficiency of the catchment modeling system calibration process. A recent developed version, swmmr, an R package of SWMM [29] is available that will help perform advanced analysis and visualizations of model data.

\section{Data and Methods}

\subsection{Description of Existing Urban Runoff Collection System}

Description of existing urban runoff and sewage collection system is summarized in terms of the sub-drainage characteristics shown in Table 1 and illustrated in Figure 1. The collection system of the study area, the City of Francistown, is divided into six sub-basins forming the current and future service areas. These basins are named according to prominent geographic or landmarks which have evolved over years of a structured urban plan. Basin characteristics of the study sub-catchment areas are also shown in Table 1 . The total area within the urban drainage area is 3982 hectares.

There are nearly 342,000 and 13,000 linear meter of gravity and pumping sewer pipes, respectively. The sewer network is served with more than 25 pumping stations. These sewer lines still in service range in size from 160 to

Table 1. Physical characteristics of the analyzed Sub Catchments.

\begin{tabular}{cccccccc}
\hline Sub Catchment & Locality & Area & & \multicolumn{2}{c}{ Elevation } & Slope & Impervious \\
Name & Name & (ha) & Min. & Max & (\%) & Area (\%) \\
\hline Sub Catchment 1 (S1) & Aerodrome & 40 & 987 & 999 & $0.7 \%$ & $40-50$ \\
Sub Catchment 2 (S2) & Central & 100 & 985 & 1004 & $1.0 \%$ & $60-70$ \\
Sub Catchment 3 (S3) & Gerald & 3203 & 991 & 1015 & $0.8 \%$ & $40-50$ \\
Sub Catchment 4 (S4) & Phase 4 & 450 & 975 & 990 & $0.7 \%$ & $50-60$ \\
Sub Catchment 5 (S5) & Satellite & 160 & 987 & 998 & $0.3 \%$ & $40-50$ \\
Sub Catchment 6 (S6) & Madzibalori & 29 & 986 & 993 & $0.9 \%$ & $50-60$ \\
System Catchment (S7) & Study area & 3982 & 985 & 1000 & $0.73 \%$ & $50-60$ \\
\hline
\end{tabular}




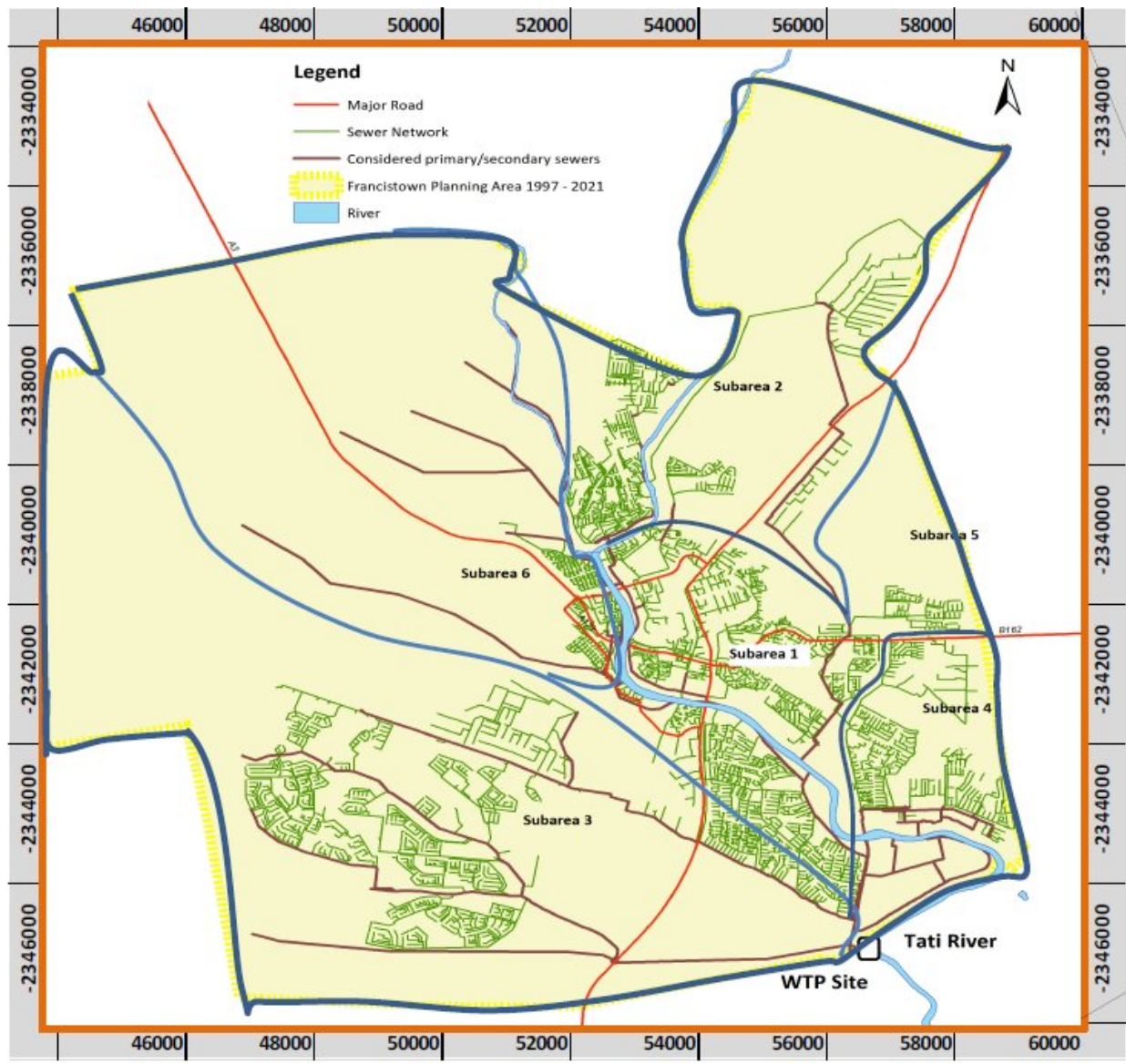

Map of Africa
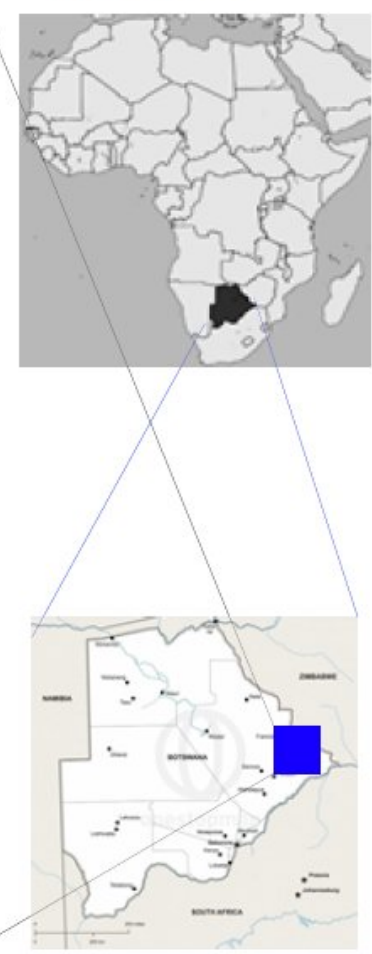

Map of Botswana

Figure 1. The urban runoff and sewerage collection system area used in the study.

$1000 \mathrm{~mm}$ in diameter, made of uPVC and concrete. The collection system consists of a network of separate sanitary sewers and storm drains, with the exception of a small area in the downstream areas of Tati River towards the sewage treatment plant and small areas used as emergency ponds near intermediate pump stations within the sewerage network. Even if emergency ponds are normally lined to manage sewage flows in separate sanitary systems, surface runoff flows during peak storms are likely to over flood these ponds thus entering sewage systems, which is a common problem in the study area.

\subsection{Field Investigations}

A variety of field investigations were performed. Every individual impervious surface was checked to estimate its hydraulic properties, including connectivity. The pavement material of every sub-catchment was observed. The pavement material and physical connectivity of every sidewalk and driveway were also investigated carefully. The fluviometric and pluviometric data used in the simulations were obtained from monitoring stations inside the studied sub-catchments. Wet weather flows from the drainage area was used to obtain peak wet weather flow data by deducting the average dry weather flow.

Using a volumetric fit of 24-hr monitored peak runoff, the UH method was 
used to determine the corresponding hourly hydrographs from the peak daily records. The subarea runoff hydrographs were also calculated by taking into account of the respective areas, imperviousness and soil infiltration parameters. These were used as maximum indicative flow rates and corresponding dates of maximum rainfall data were collected and analysed to derive hourly rainfall intensities that will be input to SWMM.

\subsection{Rainfall and Storm Events}

The rainfall data available at daily steps were used to produce hourly rainfall intensities based on a regional approach presented in [30]. Some of the rainfall events were selected and classified in groups; according to the peak wet weather runoff generated which were then discretized and used as inputs for the model calibration and validation.

The mean annual rainfall in Francistown is $442 \mathrm{~mm}$. The rainy season is from November to March and the dry period is between April and September. May to August is the coldest season with average minimum daily temperature reaching $5^{\circ} \mathrm{C}$ and hottest season is between October and January where mean maximum temperature reaches above $30^{\circ} \mathrm{C}$.

The maximum rainfall value of $1 \mathrm{hr}$ duration, the maximum $1 \mathrm{hr}$ rainfall in a year is considered. For maximum values of $2-\mathrm{hr}$ to 24 -hr rainfall duration, the maximum rainfall in a year is considered. The total duration of this rainfall event was 24-hr. Total daily rainfall on 12 Jan 2016 was $35.1 \mathrm{~mm}$ and the next highest in the same year was $33.10 \mathrm{~mm}$ on 05 Feb 2016. In 2017, the highest 24-hr rainfall depth was $43.50 \mathrm{~mm}$ on $16 \mathrm{Feb} 2017$ and the next was $42.50 \mathrm{~mm}$ on $26 \mathrm{Feb}$ 2017 as shown in Table 2. These dates coincide with the maximum wet weather flow recorded in the drainage area and these concurrent records were used for further modelling evaluations.

Table 3 shows the corresponding rainfall intensities for various durations for the considered rainfall events.

\subsection{Soil Characteristics and Infiltration Parameters}

Infiltration is often accounts for the largest portion of rainfall losses over pervious areas. Theoretically, infiltration is governed by the Richards equation [31] which requires that the relationship between soil permeability and pore water tension as a function of soil moisture content be known. In this study, the Horton's

Table 2. Details of selected storms.

\begin{tabular}{cccc}
\hline Model Process & Storm event & $\begin{array}{c}\text { 24-hr rainfall depth } \\
(\mathrm{mm})\end{array}$ & $\begin{array}{c}\text { Average Intensity } \\
(\mathrm{mm} / \mathrm{hr})\end{array}$ \\
\hline Calibration & 2016-Jan 12 & 35.10 & 1.46 \\
& 2017-Feb 16 & 43.50 & 1.81 \\
Verification & 2016-Feb 05 & 33.10 & 1.63 \\
& 2017-Feb 26 & 42.50 & 1.77 \\
\hline
\end{tabular}


Table 3. Rainfall Intensity of up to $24-\mathrm{hr} \max$ durations for the recorded maximum events observed in 2016 and 2017.

\begin{tabular}{ccccc}
\hline Storm & \multicolumn{3}{c}{ Recent peak 24-hr storm intensities (mm/hr) for events of: } \\
\cline { 2 - 5 } Duration & 2016-Jan12 & 2016-Feb05 & 2017-Jan16 & 2017-Feb26 \\
\hline 15-min max & 25.87 & 24.39 & 32.06 & 31.32 \\
30-min max & 15.58 & 14.69 & 19.31 & 18.87 \\
45-min max & 13.99 & 13.19 & 17.33 & 16.94 \\
1-hr max & 11.92 & 11.24 & 14.77 & 14.43 \\
2-hr max & 6.99 & 6.59 & 8.43 & 8.46 \\
3-hr max & 3.72 & 3.60 & 4.74 & 4.63 \\
4-hr max & 2.63 & 2.48 & 3.26 & 3.19 \\
6-hr max & 1.79 & 1.69 & 2.22 & 2.17 \\
9-hr max & 1.36 & 1.28 & 1.68 & 1.64 \\
12-hr max & 0.92 & 0.86 & 1.14 & 1.11 \\
18-hr max & 0.69 & 0.65 & 0.86 & 0.84 \\
24-hr max & 0.35 & 0.33 & 0.44 & 0.43 \\
\hline
\end{tabular}

method was used, the parameters that define the method are highly dependent on the type and condition of the soil being infiltrated. Three parameters control the Horton's infiltration model that a user must supply for each sub catchment are: the maximum or initial infiltration capacity (fo) in $\mathrm{mm} / \mathrm{hr}$, the minimum or equilibrium infiltration capacity (fc) in $\mathrm{mm} / \mathrm{hr}$ and the decay coefficient $(\mathrm{k}$ ) in $\mathrm{hr}^{-1}$. Horton parameters were assigned for each sub-catchment for the available types of soils in the study area which are predominantly sandy loam, clay loam and silty loam.

\subsection{Effect of Different Rainfall on Peak Runoff from SWMM Model}

Rainfall intensities for various durations are used as main inputs to the SWMM model. Figure 2 shows hourly distribution for two peak rainfall events in the study area employed for model calibration vis-à-vis event 1-12 Jan 2016 and event 2-16 Jan 2017. System response of the existing drainage network for the two maximum rainfall events used for calibration is shown in Figure 3.

For sub-catchment S1 to S6 and the entire system catchment S7, the variation of runoff for corresponding rainfall is simulated by considering various events data. The runoff hydrographs are illustrated as presented in Figure 4 and Figure 5. The maximum peak runoff is $2.81 \mathrm{~m}^{3} / \mathrm{s}$ from sub-catchment 3 (S3) or Gerald and the lowest peak runoff is $0.74 \mathrm{~m}^{3} / \mathrm{s}$ from sub-catchment 6 (S6) or Madzibalori. The magnitude of these maximum and minimum runoff peaks is in proportion to the relative catchment areas of the sub-catchments in the collection system.

The hydrograph of runoff from the individual contributing sub-catchments of the collection system are presented in Figure 6, and summarized in Table 4. It 
can be noted that runoff is limited to less than 12 hours in most of the watersheds due to small time of concentration and short travel time in the smaller sized water sheds of the collection system.

The inflow and outflow represent the total runoff generated from contributing sub-catchments of the collection system while the outflow is the total routed runoff hydrograph in the outfall of the entire system. The flooding hydrograph

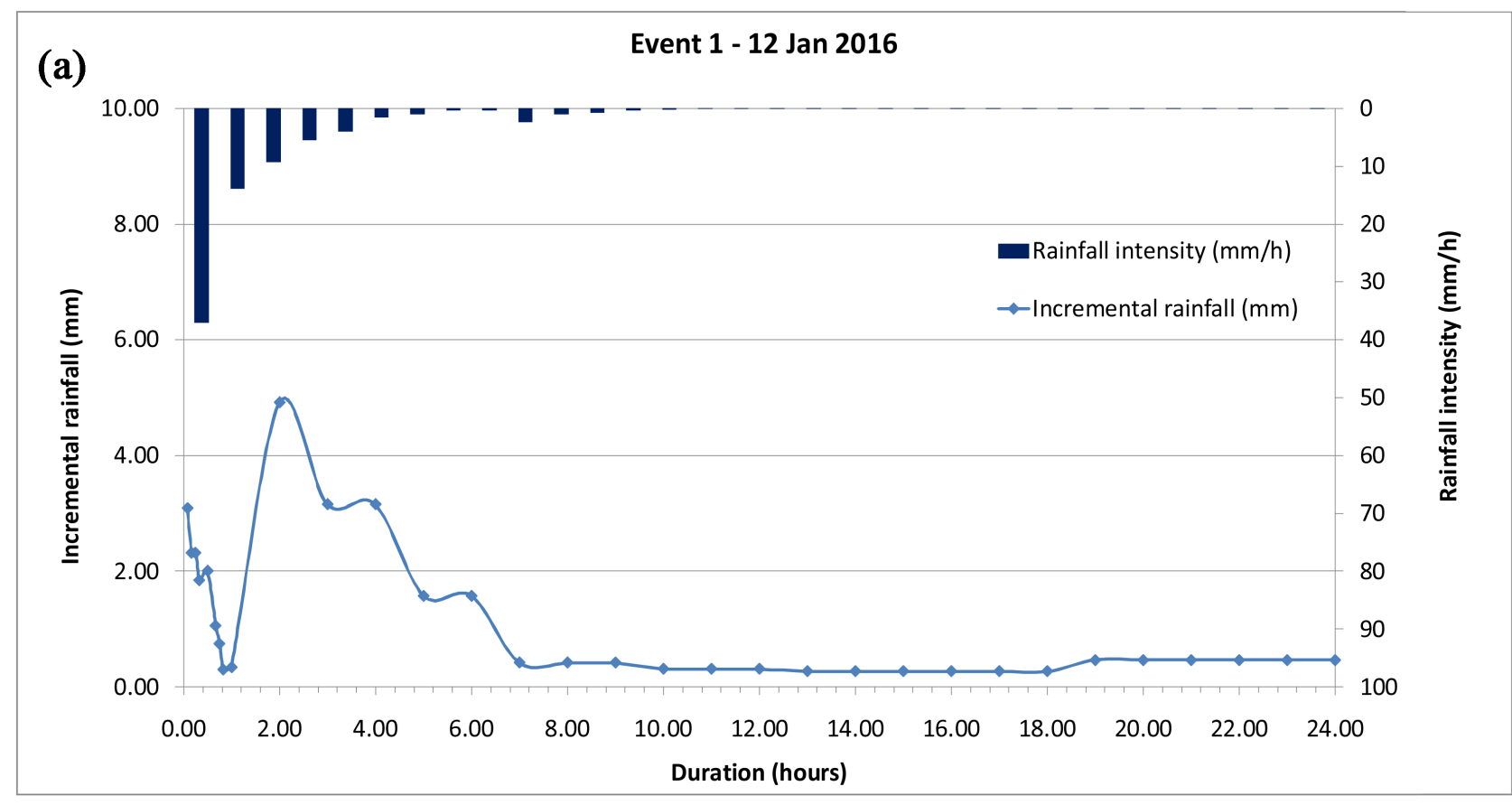

(b)

Event 2 - 16 Feb 2017

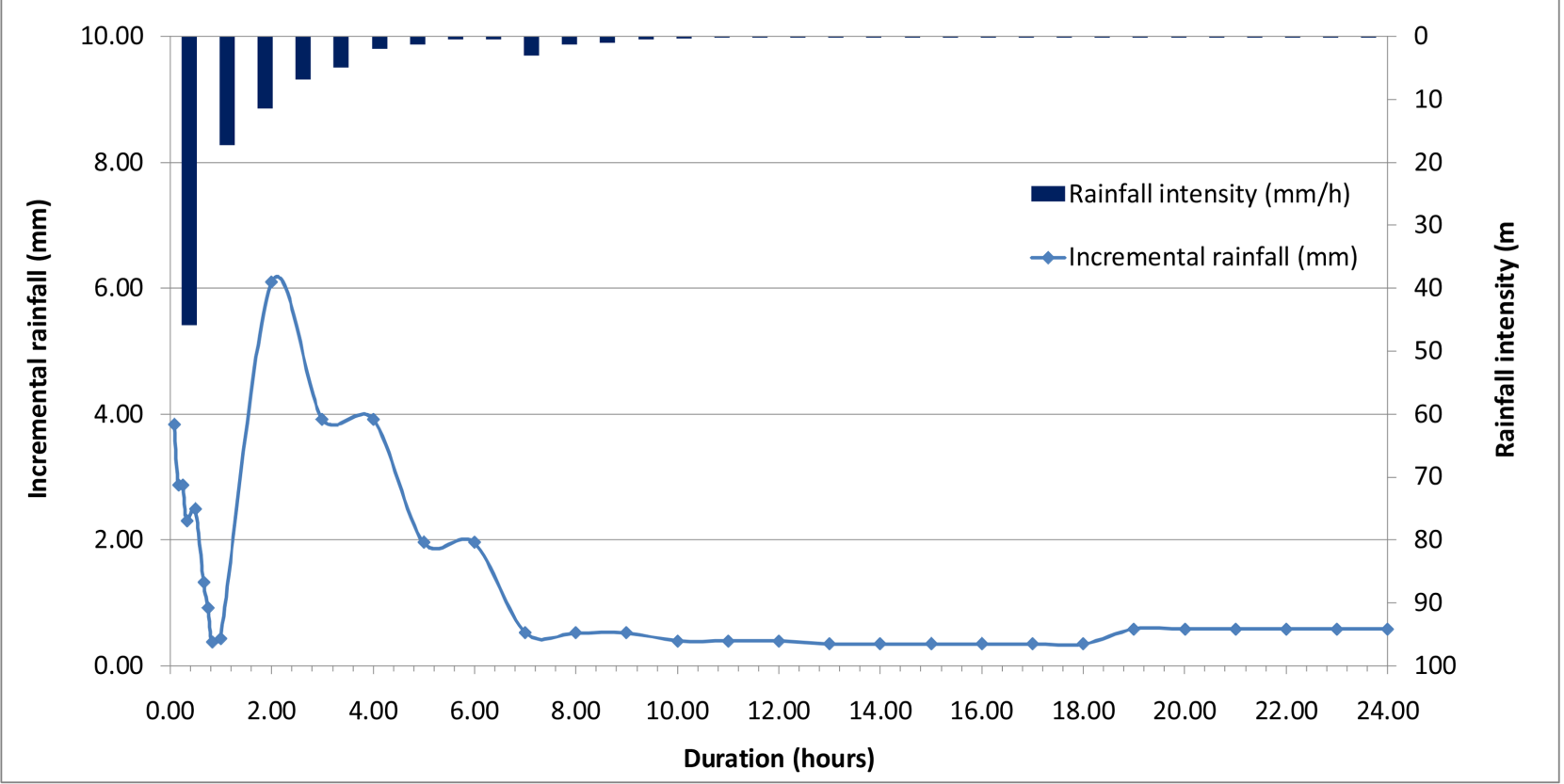

Figure 2. Hourly distribution for two peak rainfall events in the study area employed for model calibration (a) event 1-12 Jan 2016; (b) event 2-16 Jan 2017. 


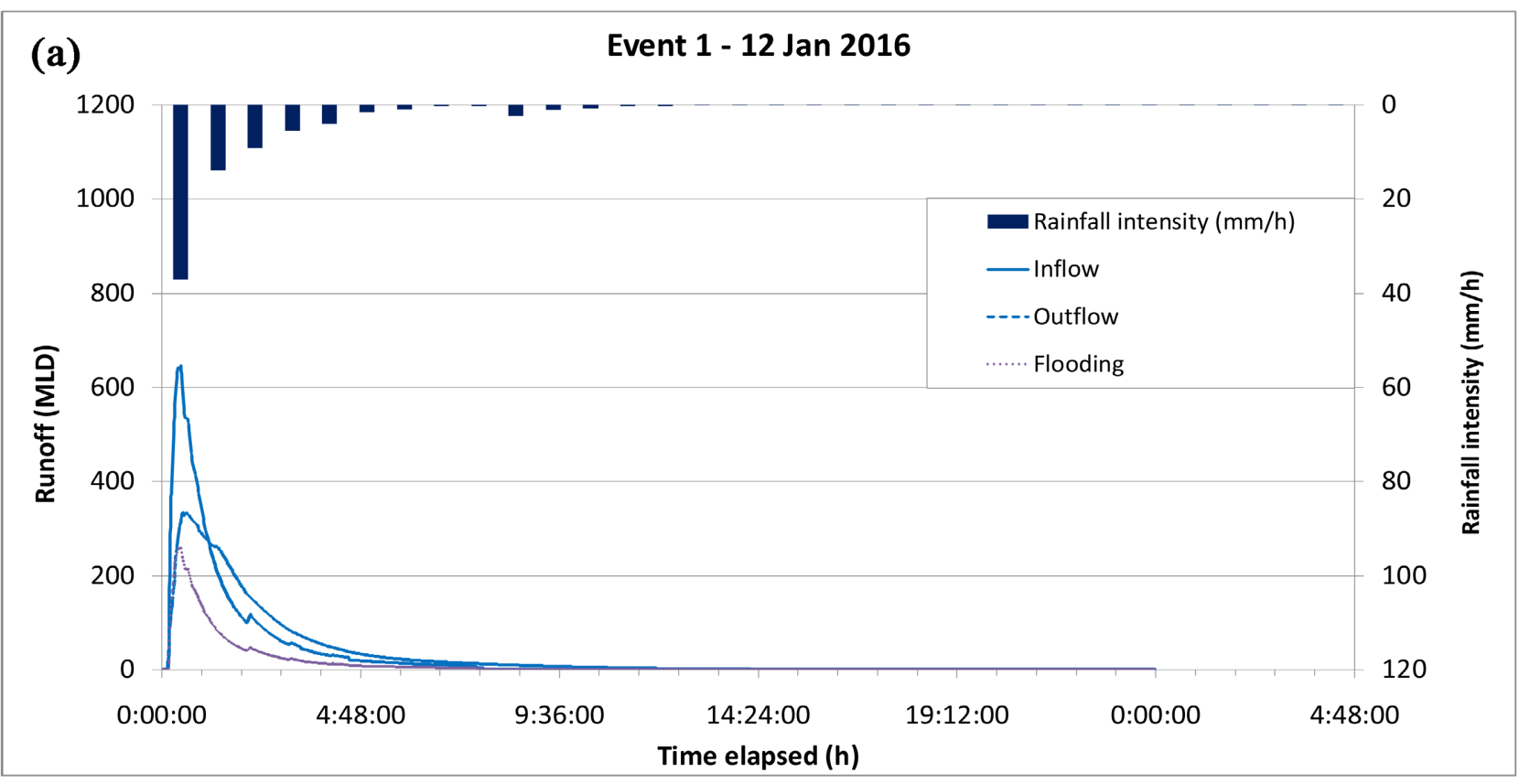

(b)

Event 2 - 16 Feb 2017

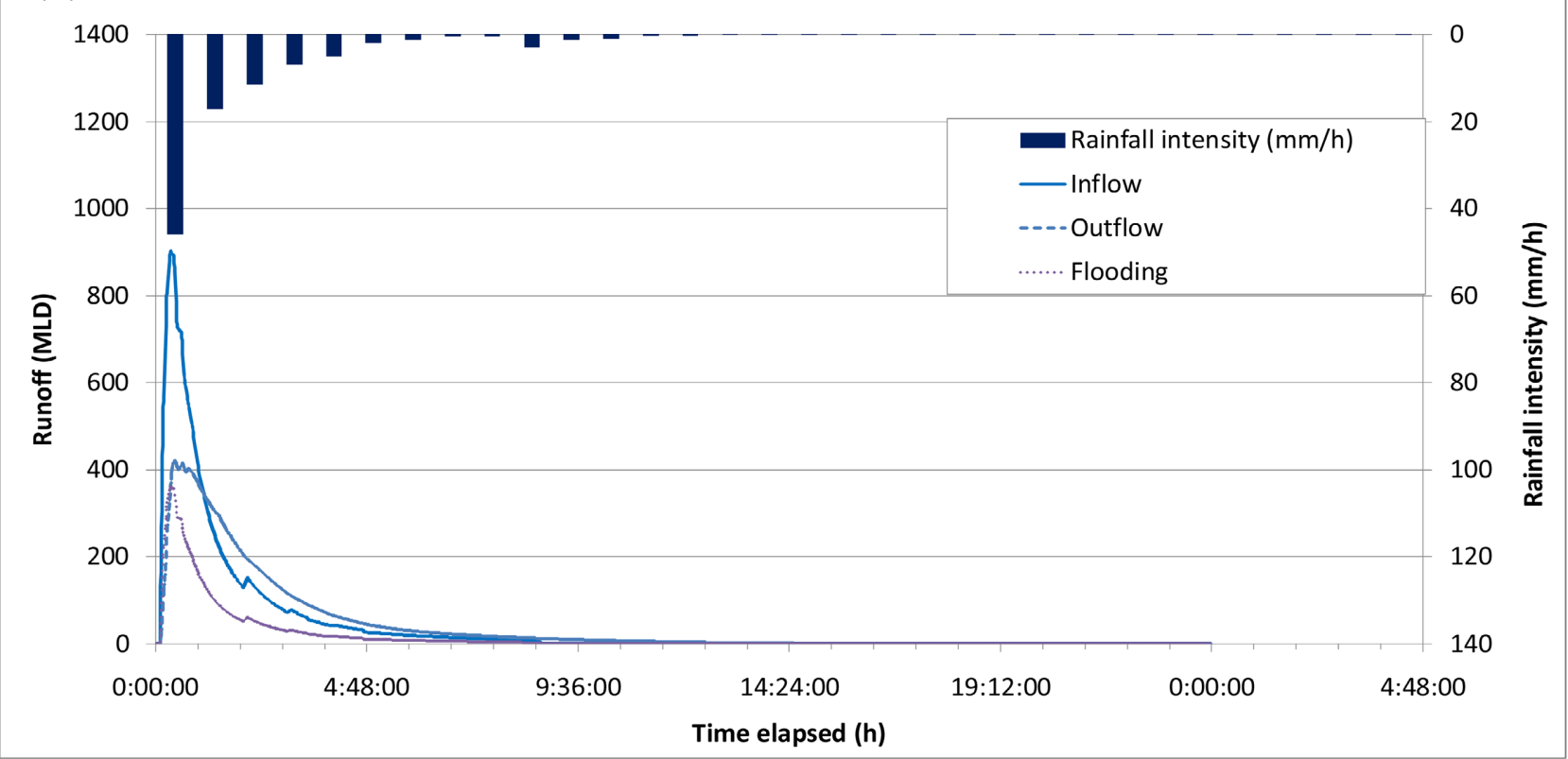

Figure 3. System response of the existing drainage network of two maximum rainfall events used for model calibration (a) event 1-12 Jan 2016; (b) event 2-16 Jan 2017.

represents that direct runoff component resulting from the corresponding storm event. The total hourly runoff peaks resulting from the particular storm event is shown in Figure 3.

\section{Discussion of Results}

\subsection{Model Efficiency Criteria}

A number of criteria were used to assess the accuracy of the modelled results 


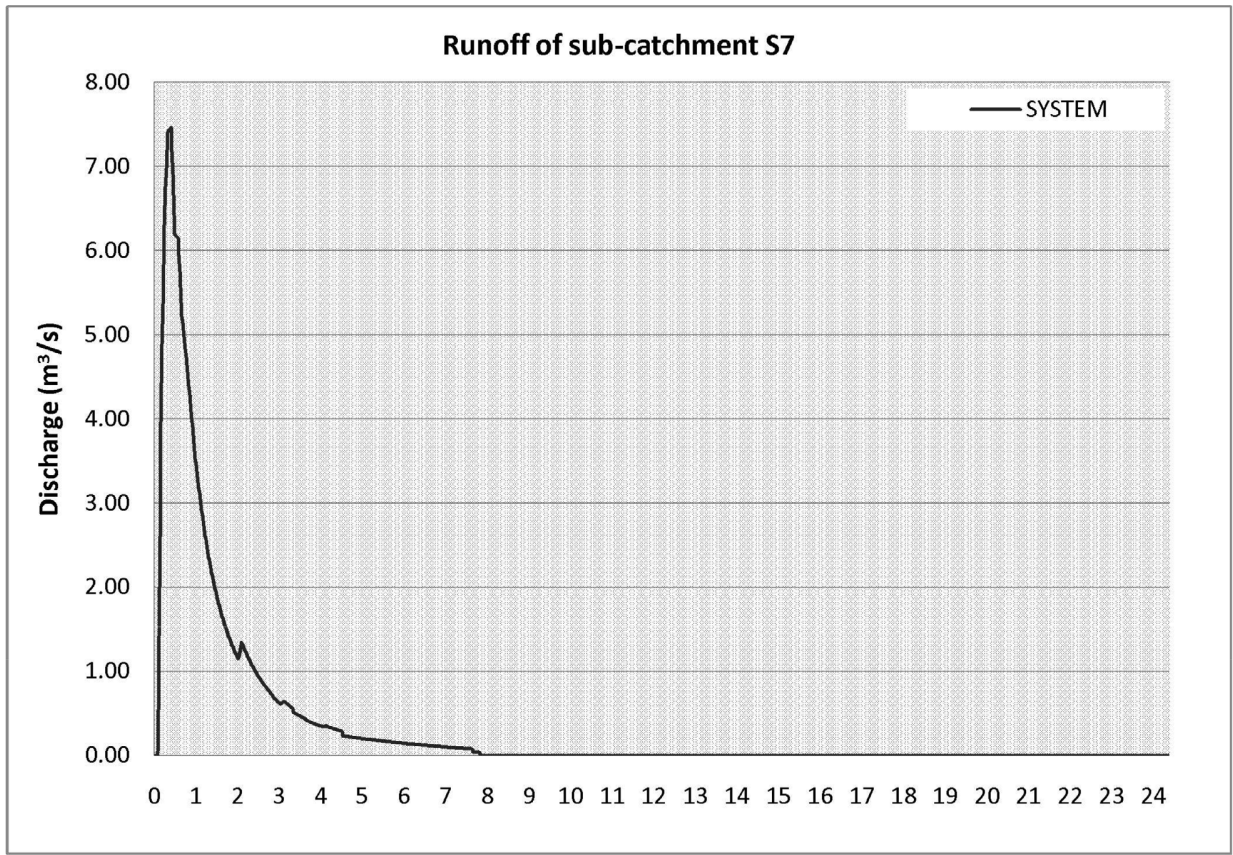

Figure 4. Runoff hydrograph of the main system catchment for rainfall event 1 of 12 Jan 2016.

Table 4. Simulated flow rates for various storm durations of storm of $12^{\text {th }}$ Jan 2016.

\begin{tabular}{cccccccc}
\hline \multirow{2}{*}{$\begin{array}{c}\text { Storm duration } \\
(\mathrm{hr})\end{array}$} & \multicolumn{6}{c}{ Runoff $\left(\mathrm{m}^{3} / \mathrm{hr}\right)$ from catchment area: } \\
\cline { 2 - 8 } $1 / 2$ & S1 & S2 & S3) & S4 & S5 & S6 & S7 \\
1 & 1222 & 984 & 5897 & 5751 & 2529 & 1738 & 17,941 \\
2 & 1098 & 890 & 2541 & 3649 & 968 & 892 & 10,071 \\
3 & 878 & 722 & 659 & 1557 & 206 & 277 & 4342 \\
4 & 674 & 557 & 171 & 699 & - & 93 & 2231 \\
5 & 509 & 424 & - & 286 & - & - & 1239 \\
6 & 372 & 313 & - & - & - & - & 696 \\
7 & 267 & 225 & - & - & - & - & 498 \\
& 183 & 153 & - & - & - & - & 340 \\
\hline
\end{tabular}

against the observed data. These model efficiency criteria considered are the Spearman's correlation coefficient (r), Nash-Sutcliffe efficiency (NSE) and RSR.

Spearman's correlation coefficient, $r$, a dimensionless quantity is used to determine the degree of linear correlation between two data sets defined by Equation (1) below. The Spearman Coefficient, $r$, can take a value between +1 to -1 where, value of +1 means a perfect association of rank.

$$
r=1-\frac{6 \sum_{i} d_{i}^{2}}{n\left(n^{2}-1\right)}
$$

where $n$ is number of data points of the two variables, and $d_{i}=$ difference in ranks of the "ith" element. 


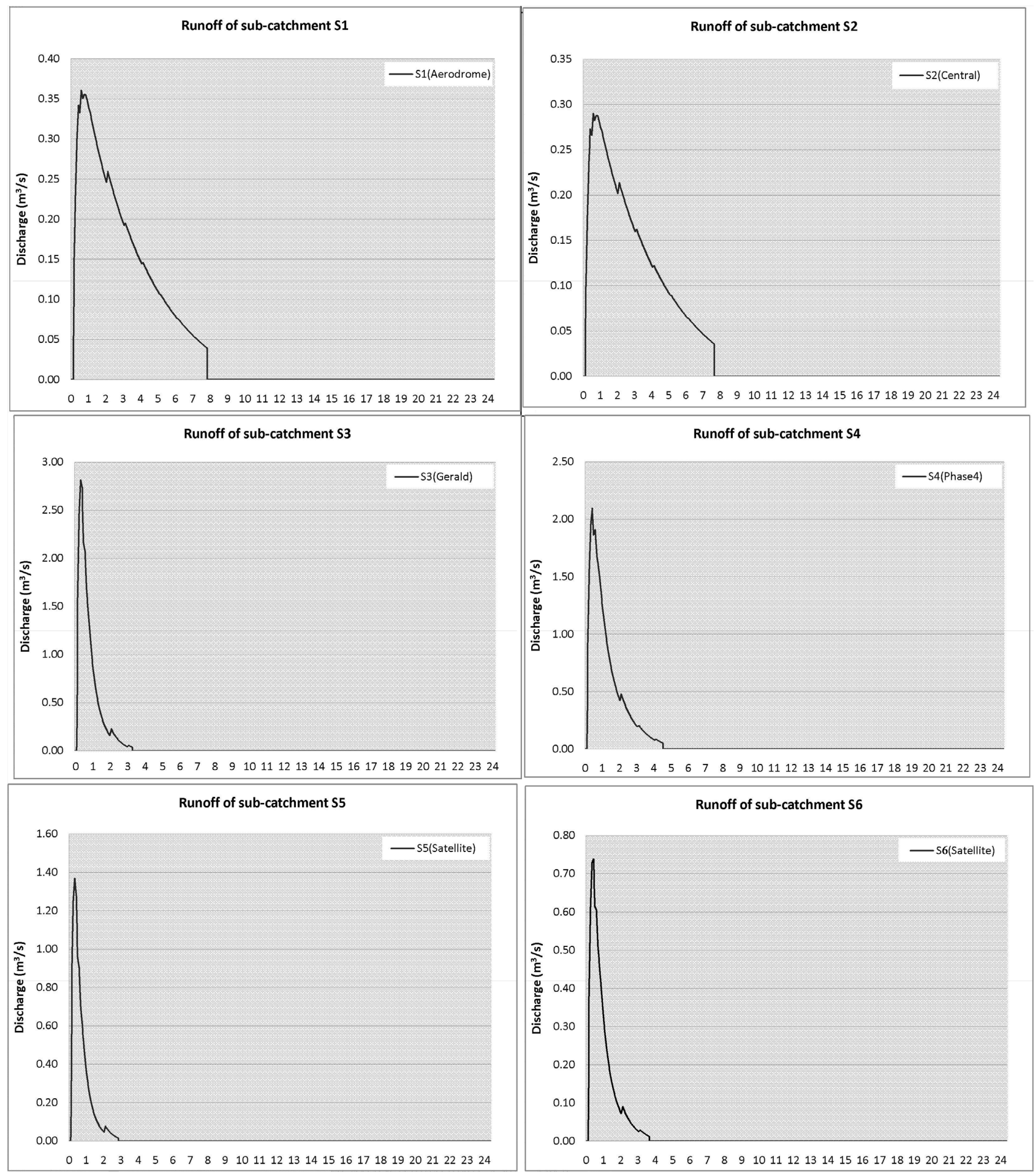

Figure 5. Runoff hydrograph of the six sub-catchments due to rainfall event 1 of 12 Jan 2016.

The Nash Sutcliffe model efficiency, known as $\mathrm{R}^{2}$ calculates the relative magnitude of the residual variance related to the variance of the observed variable $Q_{o}$. The efficiency $\mathrm{R}^{2}$ or Nash-Sutcliffe efficiency (NSE), proposed by Nash and Sutcliffe [32] is defined as one minus the sum of the absolute squared differences between the predicted and observed values normalized by the variance of the 


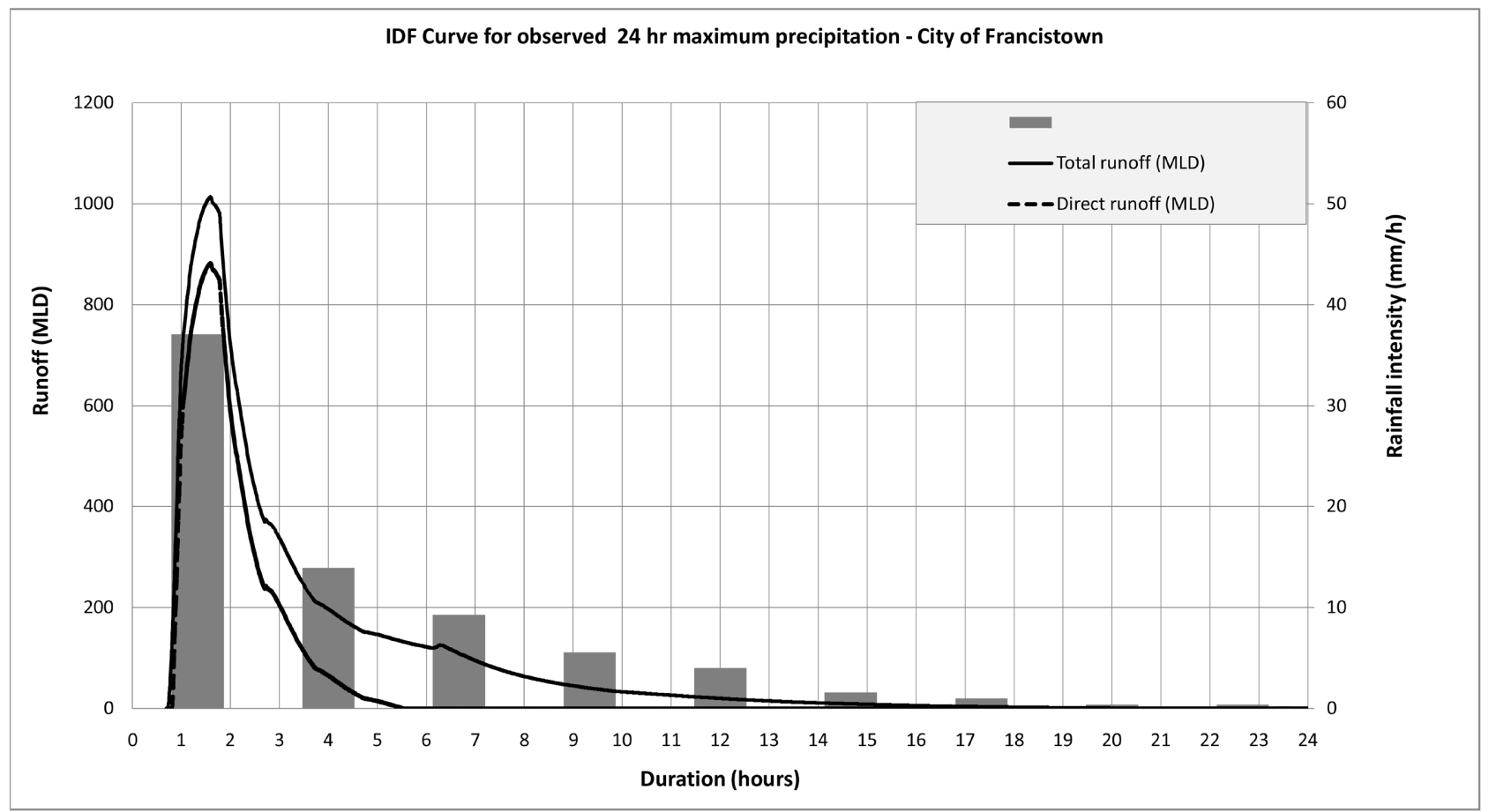

Figure 6. SWMM output of total and direct runoff hydrograph of the main system catchment due to rainfall event 1 of 12 Jan 2016.

observed values that can be multiplied by 100 to obtain NSE expressed in percentages is given by:

$$
\text { NSE }=1-\frac{\text { MSE }}{\text { Variance }}=1-\frac{\sum_{s=1}^{n}\left(Q_{o}-Q_{s}\right)^{2}}{\sum_{s=1}^{n}\left(Q_{o}-Q_{o}^{-}\right)^{2}}
$$

where MSE is the square of Root Mean Square Error (RMSE) given in Equation (3).

Correlation Coefficient, $r$, calculates the strength and direction of the linear relationship between observed and simulated. It is equivalent to the square root of the Coefficient of determination $\left(R^{2}\right)$. The range of $R^{2}$ lies between 0 and 1 which describes how much of the observed dispersion is explained by the prediction. A value of zero means no correlation at all whereas a value of 1 means that the dispersion of the prediction is equal to that of the observation.

Root Mean Square Error (RMSE): calculates the square root of the mean square value of the residual errors between the estimated quantity such as runoff $\left(Q_{s}\right)$ and the observed quantity $\left(Q_{0}\right)$.

$$
\operatorname{RMSE}=\sqrt{\left[\frac{1}{n} \sum_{s=1}^{n}\left(Q_{0}-Q_{s}\right)^{2}\right]}
$$

The model performance criteria, root-mean square ratio (RSR) or ratio of the root mean square error to the standard deviation of measured data is calculated as,

$$
\mathrm{RSR}=\frac{\mathrm{RMSE}}{\mathrm{SD}}=\frac{\left[\sqrt{\sum_{s=1}^{n}\left(Q_{o}-Q_{s}\right)^{2}}\right]}{\left[\sqrt{\sum_{s=1}^{n}\left(Q_{o}-Q_{o}^{-}\right)^{2}}\right]}
$$


The Pearson correlation coefficient, $\mathrm{r}$ is also used as model performance and assessment criteria. The coefficient of determination $\mathrm{R}^{2}$ is defined as the squared value of the coefficient of correlation $r$.

\subsection{Calibration and Validation}

Initial evaluation of results of SWMM model simulation were applied for the storm events and comparisons made with the monitored runoff of the wet weather flow data for the collection system. Wet weather flows from the drainage area flooding into the city's wastewater treatment plant was used to obtain peak wet weather flow data by deducting the average dry weather flow. Using a volumetric fit of 24-hr monitored peak runoff, the UH method was used to determine the corresponding hourly hydrographs from the peak daily records. The subarea runoff hydrographs were also calculated by taking into account of the respective areas, imperviousness and soil infiltration parameters.

In the calibration process, some observations could be made. Simplified discretizations would lead to the runoff peak greater than in detailed discretizations. In order to convert daily runoff from monitored data into hourly hydrograph ordinates, the triangular UH was used to transform the effective observed runoff to the outlet of each catchment. The peak runoff $\left(Q_{p}\right)$ from is estimated from a watershed area $A$ in $\left(\mathrm{km}^{2}\right)$ is given by Equation (5):

$$
Q_{p}=2.08 \frac{A}{T_{p}}
$$

where, $T_{p}$ is the basin lag in hours estimated as $T_{p}=0.6 T_{\mathcal{o}}$ where $T_{c}$ is the time of concentration of the watershed in hours, which depends on landcover, slope and length of the drainage that can be estimated from SCS or Kiprich.

The Kirpich equation can be also used to estimate the time of concentration in minutes for length of travel, $L$ and slope of the catchment, $S$ as;

$$
T_{c}=0.01974 \frac{L^{0.77}}{S^{0.385}}
$$

In this analysis, as the available daily volumetric monitored runoff with the time of concentration is used to determine the correct value of $Q_{p}$ in Equation (5). Hence $Q_{p}$ represents the peak runoff determined as effective triangular hydrograph with a 24 -hr volumetric quantity equal to the observed runoff with time base of 8/3Tp.

This triangular unit hydrograph has the same percentage of volume on the rising side as the dimensionless SCS unit hydrograph, where UH ordinate $\left(Q / Q_{p}\right)$ with the discharge $Q$ expressed as a ratio to the peak discharge $Q_{p}$, and the abscissa is $\left(t / T_{p}\right)$, which is the time $t$ expressed as a ratio of the time to peak, $T_{p}$. The tabulations of the coordinates of the SCS dimensionless unit hydrograph are widely available in hydrologic literature for use in developing a synthetic unit hydrograph. This procedure was applied to determine the hourly realizations of $Q$ hydrograph ordinates. 
The proportional values of imperviousness and soil infiltration parameters of each sub-catchment were used in the initial evaluation of simulated outputs along with graphical visualization of hydrographs of the observed and SWMM-simulated runoff. The initial sets of outputs were runoff coefficient, total infiltration and total evaporation as shown in Table 5 and Table 6 . These variables are related to the degree of imperviousness, land use and infiltration parameters of the existing soil types. Parameters were adjusted until reasonable match between the observed and simulated discharge hydrographs in terms of volumes, runoff peak and mean runoff is achieved. This was found to be useful as initial evaluation and visualization of hydrograph plots were made by interactively plotting SWMM outputs and observed hydrograph with a prudent adjustment of the landuse and soil infiltration parameters.

Initial analysis of results for the calibration and verification in terms of runoff coefficient, infiltration and evaporation are summarized in Table 5 and Table 6,

Table 5. Comparison between SWMM Calibration outputs in terms of runoff coefficient, total infiltration and total evaporation.

\begin{tabular}{ccccccccc}
\hline \multirow{2}{*}{$\begin{array}{c}\text { Name of } \\
\text { Catchment }\end{array}$} & \multicolumn{2}{c}{$\begin{array}{c}\text { Precipitation } \\
(\mathrm{mm})\end{array}$} & $\begin{array}{c}\text { Runoff } \\
\text { Coeff }(\mathrm{mm})\end{array}$ & \multicolumn{2}{c}{$\begin{array}{c}\text { Total } \\
\text { Infiltration }(\mathrm{mm})\end{array}$} & \multicolumn{2}{c}{ Total } \\
\cline { 2 - 9 } & Min & Max & Min & Max & Min & Min & Max & Min \\
\hline Sub Catchment 1 & 6.54 & 8.10 & 0.13 & 0.15 & 4.58 & 5.67 & 1.10 & 1.19 \\
Sub Catchment 2 & 6.54 & 8.10 & 0.12 & 0.14 & 4.58 & 5.67 & 1.18 & 1.29 \\
Sub Catchment 3 & 6.54 & 8.10 & 0.23 & 0.24 & 4.48 & 5.55 & 0.56 & 0.58 \\
Sub Catchment 4 & 6.54 & 8.10 & 0.20 & 0.21 & 4.58 & 5.67 & 0.67 & 0.70 \\
Sub Catchment 5 & 6.54 & 8.10 & 0.22 & 0.24 & 4.58 & 5.67 & 0.50 & 0.53 \\
Sub Catchment 6 & 6.54 & 8.10 & 0.21 & 0.23 & 4.58 & 5.67 & 0.57 & 0.60 \\
System area & 6.54 & 8.10 & 0.19 & 0.20 & 4.56 & 5.65 & 0.76 & 0.82 \\
\hline
\end{tabular}

Table 6. Comparison between SWMM validation outputs in terms of runoff coefficient, total infiltration and total evaporation.

\begin{tabular}{|c|c|c|c|c|c|c|c|c|}
\hline \multirow{2}{*}{$\begin{array}{l}\text { Name of } \\
\text { Catchment }\end{array}$} & \multicolumn{2}{|c|}{$\begin{array}{l}\text { Precipitation } \\
(\mathrm{mm})\end{array}$} & \multicolumn{2}{|c|}{$\begin{array}{c}\text { Runoff } \\
\text { Coeff }(\mathrm{mm})\end{array}$} & \multicolumn{2}{|c|}{$\begin{array}{c}\text { Total } \\
\text { Infiltration }(\mathrm{mm})\end{array}$} & \multicolumn{2}{|c|}{$\begin{array}{c}\text { Total } \\
\text { Evaporation }(\mathrm{mm})\end{array}$} \\
\hline & Min & $\operatorname{Max}$ & Min & $\operatorname{Max}$ & Min & Min & $\operatorname{Max}$ & Min \\
\hline Sub Catchment 1 & 6.17 & 7.92 & 0.13 & 0.15 & 4.32 & 5.54 & 1.07 & 1.18 \\
\hline Sub Catchment 2 & 6.17 & 7.92 & 0.11 & 0.14 & 4.32 & 5.54 & 1.16 & 1.27 \\
\hline Sub Catchment 3 & 6.17 & 7.92 & 0.23 & 0.24 & 4.22 & 5.42 & 0.55 & 0.58 \\
\hline Sub Catchment 4 & 6.17 & 7.92 & 0.19 & 0.21 & 4.32 & 5.54 & 0.66 & 0.69 \\
\hline Sub Catchment 5 & 6.17 & 7.92 & 0.22 & 0.23 & 4.32 & 5.54 & 0.50 & 0.52 \\
\hline Sub Catchment 6 & 6.17 & 7.92 & 0.21 & 0.23 & 4.32 & 5.54 & 0.57 & 0.60 \\
\hline System area & 6.17 & 7.92 & 0.18 & 0.20 & 4.30 & 5.52 & 0.75 & 0.81 \\
\hline
\end{tabular}


respectively.

With the procedure adopted to calibrate the events, a set of parameter combinations that led to the best fit between the observed and the simulated hydrographs was obtained for each rainfall event based model efficiency criteria namely, the Pearson correlation coefficient ( $r$ ), the Nash-Sutcliffe efficiency (NSE), root-mean square ratio (RSR) including runoff peak values and volumes from the SWMM model against observed quantities.

Table 7 and Table 8 show runoff volume, peak runoff and mean runoff of calibration dataset and validation data set, respectively. Whereas, Table 9 shows calibration results of SWMM model efficiency using Pearson correlation coefficient (r), Nash-Sutcliffe efficiency (NSE) and RSR calculated based on Equations (1), (2) and (4), respectively. The corresponding model performance indicators for validation data set are shown in Table 10 .

Computed $\mathrm{r}$ values closer to 1 mean better simulation efficiency. In general,

Table 7. Runoff volume, peak runoff and mean runoff of calibration dataset of the study urban collection system.

\begin{tabular}{ccccccccc}
\hline $\begin{array}{c}\text { Name of } \\
\text { Catchment }\end{array}$ & $\begin{array}{c}\text { Precipitation } \\
(\mathrm{mm})\end{array}$ & $\begin{array}{c}\text { Runoff volume } \\
\left(10^{6} \mathrm{~L}\right)\end{array}$ & $\begin{array}{c}\text { Peak Runoff } \\
\left(\mathrm{m}^{3} / \mathrm{s}\right)\end{array}$ & $\begin{array}{c}\text { Mean Runoff } \\
\left(\mathrm{m}^{3} / \mathrm{s}\right)\end{array}$ \\
\cline { 2 - 9 } & Min & Max & Min & Max & Min & Min & Max & Min \\
\hline Sub Catchment 1 & 6.54 & 8.10 & 4.82 & 6.93 & 0.36 & 0.52 & 0.05 & 0.08 \\
Sub Catchment 2 & 6.54 & 8.10 & 3.97 & 5.84 & 0.29 & 0.42 & 0.04 & 0.07 \\
Sub Catchment 3 & 6.54 & 8.10 & 7.96 & 10.44 & 2.81 & 3.92 & 0.09 & 0.12 \\
Sub Catchment 4 & 6.54 & 8.10 & 9.70 & 13.01 & 2.10 & 2.98 & 0.11 & 0.15 \\
Sub Catchment 5 & 6.54 & 8.10 & 3.36 & 4.38 & 1.37 & 1.88 & 0.04 & 0.05 \\
Sub Catchment 6 & 6.54 & 8.10 & 2.50 & 3.30 & 0.74 & 1.03 & 0.03 & 0.04 \\
System area & 6.54 & 8.10 & 32.38 & 41.74 & 3.85 & 4.88 & 0.37 & 0.48 \\
\hline
\end{tabular}

Table 8. Runoff volume, peak runoff and mean runoff of verification dataset of the study urban collection system.

\begin{tabular}{ccccccccc}
\hline $\begin{array}{c}\text { Name of } \\
\text { Catchment }\end{array}$ & $\begin{array}{c}\text { Precipitation } \\
(\mathrm{mm})\end{array}$ & $\begin{array}{c}\text { Runoff volume } \\
\left(10^{6} \mathrm{~L}\right)\end{array}$ & $\begin{array}{c}\text { Peak Runoff } \\
\left(\mathrm{m}^{3} / \mathrm{s}\right)\end{array}$ & $\begin{array}{c}\text { Mean Runoff } \\
\left(\mathrm{m}^{3} / \mathrm{s}\right)\end{array}$ \\
\cline { 2 - 9 } & Min & Max & Min & Max & Min & Min & Max & Min \\
\hline Sub Catchment 1 & 6.17 & 7.92 & 4.34 & 6.67 & 0.33 & 0.50 & 0.05 & 0.07 \\
Sub Catchment 2 & 6.17 & 7.92 & 3.54 & 5.61 & 0.26 & 0.41 & 0.04 & 0.06 \\
Sub Catchment 3 & 6.17 & 7.92 & 7.37 & 10.14 & 2.56 & 3.79 & 0.08 & 0.12 \\
Sub Catchment 4 & 6.17 & 7.92 & 8.92 & 12.61 & 1.90 & 2.87 & 0.10 & 0.14 \\
Sub Catchment 5 & 6.17 & 7.92 & 3.11 & 4.26 & 1.25 & 1.82 & 0.04 & 0.05 \\
Sub Catchment 6 & 6.17 & 7.92 & 2.31 & 3.20 & 0.67 & 0.99 & 0.03 & 0.04 \\
System area & 6.17 & 7.92 & 30.12 & 40.63 & 3.66 & 4.74 & 0.35 & 0.47 \\
\hline
\end{tabular}


Table 9. Model performance for calibration datasets in terms of Pearson correlation coefficient ( $r$ ), Nash-Sutcliffe efficiency (NSE) and RSR.

\begin{tabular}{ccccccc}
\hline \multirow{2}{*}{ Name of Catchment } & \multicolumn{2}{c}{ R } & \multicolumn{2}{c}{ NSE (\%) } & \multicolumn{2}{c}{ RSR } \\
\cline { 2 - 7 } & Min & Max & Min & Max & Max & Min \\
\hline Sub Catchment 1 & 0.541 & 0.543 & $75.8 \%$ & $77.2 \%$ & 0.48 & 0.49 \\
Sub Catchment 2 & 0.539 & 0.541 & $72.2 \%$ & $72.4 \%$ & 0.53 & 0.53 \\
Sub Catchment 3 & 0.772 & 0.786 & $75.1 \%$ & $78.5 \%$ & 0.46 & 0.50 \\
Sub Catchment 4 & 0.669 & 0.684 & $40.9 \%$ & $44.3 \%$ & 0.75 & 0.77 \\
Sub Catchment 5 & 0.798 & 0.813 & $62.4 \%$ & $62.6 \%$ & 0.61 & 0.61 \\
Sub Catchment 6 & 0.734 & 0.754 & $87.8 \%$ & $89.0 \%$ & 0.33 & 0.35 \\
System area & 0.590 & 0.595 & $64.5 \%$ & $77.5 \%$ & 0.47 & 0.60 \\
\hline
\end{tabular}

Table 10. Model performance for validation datasets in terms of Pearson correlation coefficient (r), Nash-Sutcliffe efficiency (NSE) and RSR.

\begin{tabular}{ccccccc}
\hline \multirow{2}{*}{ Name of Catchment } & \multicolumn{2}{c}{ R } & \multicolumn{2}{c}{ NSE (\%) } & \multicolumn{2}{c}{ RSR } \\
\cline { 2 - 7 } & Min & Max & Min & Max & Max & Min \\
\hline Sub Catchment 1 & 0.541 & 0.543 & $75.4 \%$ & $77.1 \%$ & 0.48 & 0.50 \\
Sub Catchment 2 & 0.539 & 0.541 & $72.2 \%$ & $72.3 \%$ & 0.53 & 0.53 \\
Sub Catchment 3 & 0.767 & 0.784 & $74.3 \%$ & $78.1 \%$ & 0.47 & 0.51 \\
Sub Catchment 4 & 0.666 & 0.682 & $42.2 \%$ & $43.1 \%$ & 0.75 & 0.76 \\
Sub Catchment 5 & 0.795 & 0.812 & $60.8 \%$ & $63.4 \%$ & 0.60 & 0.63 \\
Sub Catchment 6 & 0.729 & 0.752 & $87.1 \%$ & $89.0 \%$ & 0.33 & 0.36 \\
System area & 0.589 & 0.593 & $66.3 \%$ & $79.6 \%$ & 0.45 & 0.58 \\
\hline
\end{tabular}

model simulation can be judged as satisfactory if NSE $>50 \%$ and RSR $<0.70$, which can be used as constituent-specific performance ratings given uncertainty of fewer and discretized measured runoff data.

The RSR performance of the SWMM model in catchment 4 (S4) has is unfavorable where RSR values ranges of 0.75 to 077 , and NSE in the range of $40 \%$ $44 \%$ indicating poor performance, where the model has underestimated observed flows, as tabulated in Tables 11-13. The model performance was adequate in the remaining 6 catchments considered in the SWMM modelling effort for the study area. Even though a mix of underestimation and overestimation in the hydrographs is prevalent, though insignificant, in most parts of the hydrograph is evident in terms of the $75 \%, 50 \%$ and $25 \%$ quantile flow regimes as presented in Table 11 and Table 12.

\subsection{Parameter Sensitivity Analysis}

Parameter sensitivity analysis was conducted on the events with the best results from the calibration exercise. The analysis was used to evaluate the main para- 
meters that control the peak and volume of runoff. Starting from the set of parameters that led to the best calibrations per sub-basin (sub catchment), one parameter was varied at a time in fixed percentage increments, whose results were tabulated and compared.

Parameter sensitivity analysis was conducted on the events with the best results from the calibration exercise and the sensitivity analysis was performed by changing each parameter while keeping all others constant and observing the changes in model output. The analysis was used to evaluate the main parameters involved in terms of peak and volume of runoff. The percent changes in runoff volume and peak runoff were most sensitive to changes in imperviousness and storage. Changes in all other parameter were small and sometimes insignificant to runoff changes.

A factor of $10 \%$ was used to vary the input parameters that control the runoff characteristics mainly the infiltration and surface roughness and land use factors, and the resulting runoff characteristics including total depth of runoff, volume of runoff and runoff coefficient, which were used to compute the impact on the model performance criteria, namely, the Pearson correlation coefficient (r), the Nash-Sutcliffe efficiency (NSE), root-mean square ratio (RSR). The simulated runoff characteristics in the output of the system conceptualization of SWMM that are compared to those determined from the real-world measurements of monitored data. Figure 7 shows the percentage change in simulated SWIMM runoff volume, total depth and runoff coefficient for percentage changes of infiltration and catchment parameters. In Figure 7, the infiltration parameters considered are the maximum or initial infiltration capacity (fo) in $\mathrm{mm} / \mathrm{hr}$, the minimum or equilibrium infiltration capacity (fc) in $\mathrm{mm} / \mathrm{hr}$ and the decay coefficient (k) in hr-1 and catchment characteristics considered are imperviousness, slope and Manning's $n$ of pervious area. From Figure 7 it can be said that generally increases in values of infiltration parameters results in decreases in runoff and vice versa. It can be seen from Figure 7 that increases in imperviousness also showed increases in runoff and vise versa. It can be deduced also that $10 \%-20 \%$ increases in pervious area $\mathrm{n}$ coefficient would result in decreases up to $20 \%$ of volume and runoff coefficient, and up to $10 \%$ of runoff depth.

Runoff characteristics for watersheds for calibration and validation datasets are presented in Table 11 and Table 12.

There is some but fairly distributed variation in the minimum and maximum values in all the watersheds of the study area. Besides the peak runoff, the descending runoff magnitudes of 75, 50 and 25 percent quantile runoff magnitudes (Q75, Q50 and Q25) are indicated. On the same table, the deviation of these quantiles of the observed runoff and those of the SWMM model simulated values are shown.

The changes in these quantities are in general between $\pm 10 \%$ indicating reasonable matching of the hydrographs, even though there are few cases where deviations go beyond this range. There is generally higher range in the change of 

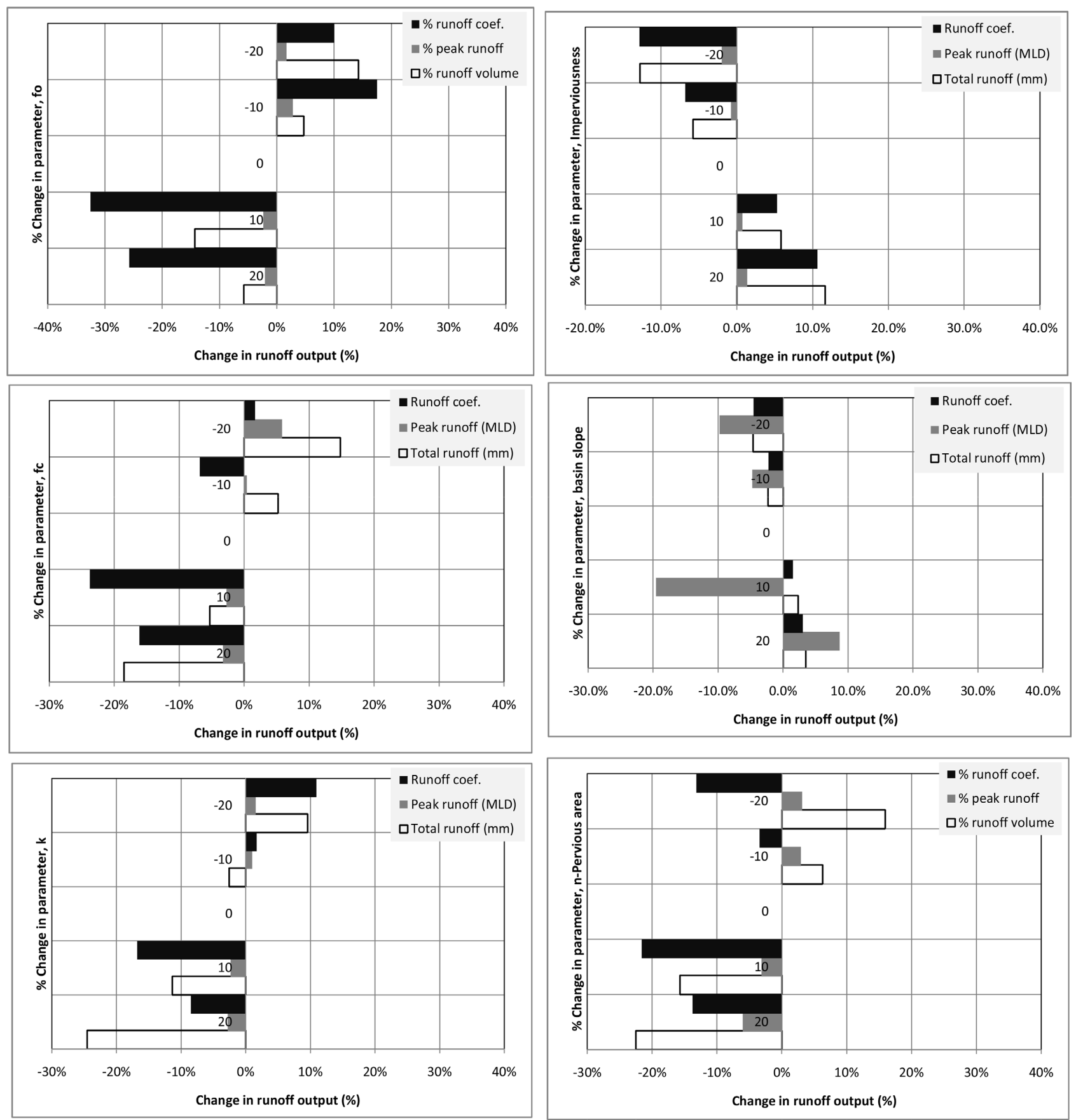

Figure 7. Percentage change in simulated SWIMM runoff volume, total depth and runoff coefficient for percentage changes of infiltration and catchment parameters.

lower runoff quantiles Q25 compared to Q50 and Q75.

The one-hr runoff simulated with SWMM in comparison with the observed runoff is presented in Table 13. In the calibration process, some observations could be made. In simplified discretizations of time steps, the runoff peak is greater than in detailed discretizations as noted in similar studies [10]. Reduction in time was noted in simplified discretization with an average value. It is possible to conclude that in natural river beds, when the water level grows until 
Table 11. Runoff characteristics for calibration datasets.

\begin{tabular}{|c|c|c|c|c|c|c|c|c|}
\hline \multirow{2}{*}{\multicolumn{2}{|c|}{$\begin{array}{l}\text { Observed runoff and changes } \\
\text { vs modelled run-off }\end{array}$}} & \multicolumn{7}{|c|}{ Name of catchment } \\
\hline & & \multirow{2}{*}{$\begin{array}{c}\text { S } 1 \\
1241\end{array}$} & \multirow{2}{*}{$\begin{array}{c}\text { S } 2 \\
1001\end{array}$} & \multirow{2}{*}{$\begin{array}{c}\text { S } 3 \\
6747\end{array}$} & \multirow{2}{*}{$\begin{array}{c}\text { S } 4 \\
6086\end{array}$} & \multirow{2}{*}{$\begin{array}{c}\text { S } 5 \\
2951\end{array}$} & \multirow{2}{*}{$\begin{array}{c}\text { S } 6 \\
1959\end{array}$} & \multirow{2}{*}{$\begin{array}{c}\text { System area } \\
12,650\end{array}$} \\
\hline Q75 (Obs) $\left(\mathrm{m}^{3} / \mathrm{s}\right)$ & Min & & & & & & & \\
\hline [Upper quantile] & Max & 1779 & 1460 & 8922 & 8465 & 3832 & 2625 & 16,400 \\
\hline \multirow{2}{*}{$\begin{array}{c}\text { Q50 (Obs) }\left(\mathrm{m}^{3} / \mathrm{s}\right) \\
\text { [Median value] }\end{array}$} & Min & 1148 & 931 & 3459 & 4247 & 1324 & 1132 & 10,990 \\
\hline & Max & 1638 & 1351 & 4256 & 5678 & 1668 & 1426 & 13,807 \\
\hline \multirow{2}{*}{$\begin{array}{l}\text { Q25 (Obs) }\left(\mathrm{m}^{3} / \mathrm{s}\right) \\
\text { [Lower quantile] }\end{array}$} & Min & 725 & 598 & 293 & 913 & 52 & 139 & 3946 \\
\hline & Max & 1015 & 855 & 373 & 1147 & 106 & 172 & 5164 \\
\hline \multirow{2}{*}{$\begin{array}{l}\Delta \mathrm{Q} 75(\%) \\
{[\% \text { change }]}\end{array}$} & Min & $-4.0 \%$ & $-14.1 \%$ & $-4.1 \%$ & $1.1 \%$ & $-1.4 \%$ & $-4.9 \%$ & $0.0 \%$ \\
\hline & Max & $7.2 \%$ & $15.8 \%$ & $2.2 \%$ & $1.9 \%$ & $0.4 \%$ & $3.1 \%$ & $0.5 \%$ \\
\hline \multirow{2}{*}{$\begin{array}{c}\Delta \mathrm{Q} 50(\%) \\
{[\% \text { change }]}\end{array}$} & Min & $-3.0 \%$ & $6.6 \%$ & $-3.1 \%$ & $-0.3 \%$ & $-0.2 \%$ & $-1.6 \%$ & $-0.1 \%$ \\
\hline & $\operatorname{Max}$ & $-2.0 \%$ & $18.1 \%$ & $1.0 \%$ & $0.1 \%$ & $0.2 \%$ & $1.0 \%$ & $0.6 \%$ \\
\hline \multirow{2}{*}{$\begin{array}{l}\Delta \mathrm{Q} 25(\%) \\
{[\% \text { change }]}\end{array}$} & Min & $0.4 \%$ & $-4.7 \%$ & $2.0 \%$ & $-0.1 \%$ & $-2.1 \%$ & $-2.0 \%$ & $0.2 \%$ \\
\hline & Max & $2.1 \%$ & $9.9 \%$ & $4.4 \%$ & $0.7 \%$ & $1.1 \%$ & $0.7 \%$ & $0.4 \%$ \\
\hline
\end{tabular}

Table 12. Runoff characteristics for validation datasets.

\begin{tabular}{|c|c|c|c|c|c|c|c|c|}
\hline \multirow{2}{*}{\multicolumn{2}{|c|}{$\begin{array}{l}\text { Observed runoff and changes } \\
\text { vs modelled run-off }\end{array}$}} & \multicolumn{7}{|c|}{ Name of catchment } \\
\hline & & \multirow{2}{*}{$\begin{array}{c}\text { S } 1 \\
1125\end{array}$} & \multirow{2}{*}{$\begin{array}{l}\text { S } 2 \\
902\end{array}$} & \multirow{2}{*}{$\begin{array}{c}\text { S } 3 \\
6237\end{array}$} & \multirow{2}{*}{$\begin{array}{c}\text { S } 4 \\
5567\end{array}$} & \multirow{2}{*}{$\frac{\text { S } 5}{2752}$} & \multirow{2}{*}{$\begin{array}{c}\text { S } 6 \\
1800\end{array}$} & \multirow{2}{*}{$\begin{array}{c}\text { System area } \\
11,799\end{array}$} \\
\hline Q75 (Obs) $\left(\mathrm{m}^{3} / \mathrm{s}\right)$ & Min & & & & & & & \\
\hline [Upper quantile] & Max & 1711 & 1402 & 8676 & 8164 & 3710 & 2547 & 16,013 \\
\hline \multirow{2}{*}{$\begin{array}{l}\text { Q50 (Obs) }\left(\mathrm{m}^{3} / \mathrm{s}\right) \\
{[\text { Median value] }}\end{array}$} & Min & 1041 & 837 & 3256 & 3927 & 1254 & 1059 & 10,484 \\
\hline & Max & 1577 & 1298 & 4165 & 5517 & 1634 & 1392 & 13,469 \\
\hline \multirow{2}{*}{$\begin{array}{l}\text { Q25 }(\mathrm{Obs})\left(\mathrm{m}^{3} / \mathrm{s}\right) \\
\text { [Lower quantile] }\end{array}$} & Min & 658 & 539 & 274 & 854 & 49 & 131 & 3655 \\
\hline & Max & 979 & 824 & 362 & 1120 & 61 & 169 & 5020 \\
\hline \multirow{2}{*}{$\begin{array}{l}\Delta \mathrm{Q} 75(\%) \\
{[\% \text { change }]}\end{array}$} & Min & $-2.6 \%$ & $-8.6 \%$ & $2.6 \%$ & $0.6 \%$ & $-1.4 \%$ & $-3.7 \%$ & $-3.1 \%$ \\
\hline & Max & $2.4 \%$ & $3.0 \%$ & $4.8 \%$ & $0.7 \%$ & $-1.4 \%$ & $4.2 \%$ & $-1.1 \%$ \\
\hline \multirow{2}{*}{$\begin{array}{l}\Delta \mathrm{Q} 50(\%) \\
{[\% \text { change }]}\end{array}$} & Min & $-0.2 \%$ & $10.4 \%$ & $-1.7 \%$ & $-0.7 \%$ & $0.1 \%$ & $0.0 \%$ & $-0.8 \%$ \\
\hline & Max & $0.1 \%$ & $11.8 \%$ & $2.5 \%$ & $-0.7 \%$ & $0.2 \%$ & $1.3 \%$ & $-0.6 \%$ \\
\hline \multirow{2}{*}{$\begin{array}{l}\Delta \mathrm{Q} 25(\%) \\
{[\% \text { change }]}\end{array}$} & Min & $-0.6 \%$ & $7.1 \%$ & $-0.4 \%$ & $0.2 \%$ & $1.0 \%$ & $-5.4 \%$ & $-0.7 \%$ \\
\hline & Max & $3.5 \%$ & $10.6 \%$ & $0.5 \%$ & $0.9 \%$ & $2.1 \%$ & $-2.8 \%$ & $-0.1 \%$ \\
\hline
\end{tabular}

the bank-full depth, the Manning's decreases [33] [34]. However, when this depth is extrapolated, the flow finds greater resistance due to the distinct composition of the boundaries, especially because of the vegetation, usually denser in along drainage/stream channels. This profile is also observed in the analyzed watersheds, where a vegetated transition zone can be found between the stream zones and the impervious areas. 
Table 13. One-hr runoff by SWMM in comparison with the observed runoff.

\begin{tabular}{ccc}
\hline Catchment Name & SWMM model runoff $\left(\mathrm{m}^{3} / \mathrm{hr}\right)$ & Observed runoff $\left(\mathrm{m}^{3} / \mathrm{hr}\right)$ \\
\hline Sub Catchment 1 & 1107 & 1148 \\
Sub Catchment 2 & 914 & 931 \\
Sub Catchment 3 & 3443 & 3459 \\
Sub Catchment 4 & 4221 & 4247 \\
Sub Catchment 5 & 1321 & 1324 \\
Sub Catchment 6 & 1125 & 1132 \\
System area & 11,589 & 12,430 \\
\hline
\end{tabular}

Table 14. Performance of SWMM model.

\begin{tabular}{ccc}
\hline $\begin{array}{c}\text { Name of } \\
\text { Catchment }\end{array}$ & $\begin{array}{c}\text { SWMM model } \\
\text { runoff }\left(\mathrm{m}^{3} / \mathrm{hr}\right)\end{array}$ & $\begin{array}{c}\text { Simulated flow velocity from } \\
\text { Manning's formula }(\mathrm{m} / \mathrm{sec})\end{array}$ \\
\hline Sub Catchment 1 & 1107 & 0.76 \\
Sub Catchment 2 & 914 & 0.86 \\
Sub Catchment 3 & 3443 & 0.64 \\
Sub Catchment 4 & 4221 & 0.95 \\
Sub Catchment 5 & 1321 & 0.84 \\
Sub Catchment 6 & 1125 & 0.95 \\
System area & 11,589 & 0.79 \\
\hline
\end{tabular}

To check the existing drainage adequacy, peak discharge were used to estimate flow velocities. The Manning's equation gives the value of velocity of water in each drainage channel if the cross section area of channel is known [34]. Table 14 shows the performance of SWMM in terms of evaluating flow velocities in receiving channels. As the impervious cover increases or rainfall intensity increases in future, the peak discharge may exceed the design capacity of existing channel in sub catchment 4 and 6, where flow velocity is already high. To control the runoff on these sub catchments, there must be measures in future that can reduce the runoff such as introduction of continuous permeable pavements or infiltration trenches to improve infiltration.

\section{Conclusions}

Results of SWMM model runoff hydrographs from calibrated datasets and calibration datasets compared to observed hydrographs from the collection system are comparable. The runoff coefficient is found to range between 0.12 and 0.24 in the studied catchments. Qualitatively speaking the hydrographs of SWMM model outputs and those observed during those rainfall events are visually similar, and they were used to set the final model parameters of each drainage catchment. The hydrographs were finally examined in an interactive manner to ar- 
rive at optimal model efficiency criteria, where the model performance of SWMM in reproducing the observed runoff hydrographs was judged. The calibrated model was able to predict the observed outputs with reasonable accuracy for calibration datasets of two peak flood events of 2016-Jan 12 and 2017-Feb 16 and verification flood events of 2016-Feb 05 and 2017-Feb 26, Figure 8.

For six watersheds that drain the study area considered with a seventh entire collection system catchment area, we have found that correlation coefficients range from 0.539 to 0.813 and NSE ranges from $40.9 \%$ to $89.0 \%$, and RSR ranges from 0.330 to 0.812 for the calibration datasets. Whereas, for the verification dataset, the correlation coefficients range from 0.539 to 0.813 and NSE values range from $40.9 \%$ to $89.0 \%$, and RSR values range from 0.330 to 0.812 . Generally the correlation coefficients and RSR values do not differ significantly among the two data sets, whereas NSE values differ significantly as NSE considers the variance unaccounted for by the model as shown in Equation (2).

The results obtained using the Pearson's correlation coefficient and the SWMM model software is almost equal to the observed values. As shown in Figure 8,

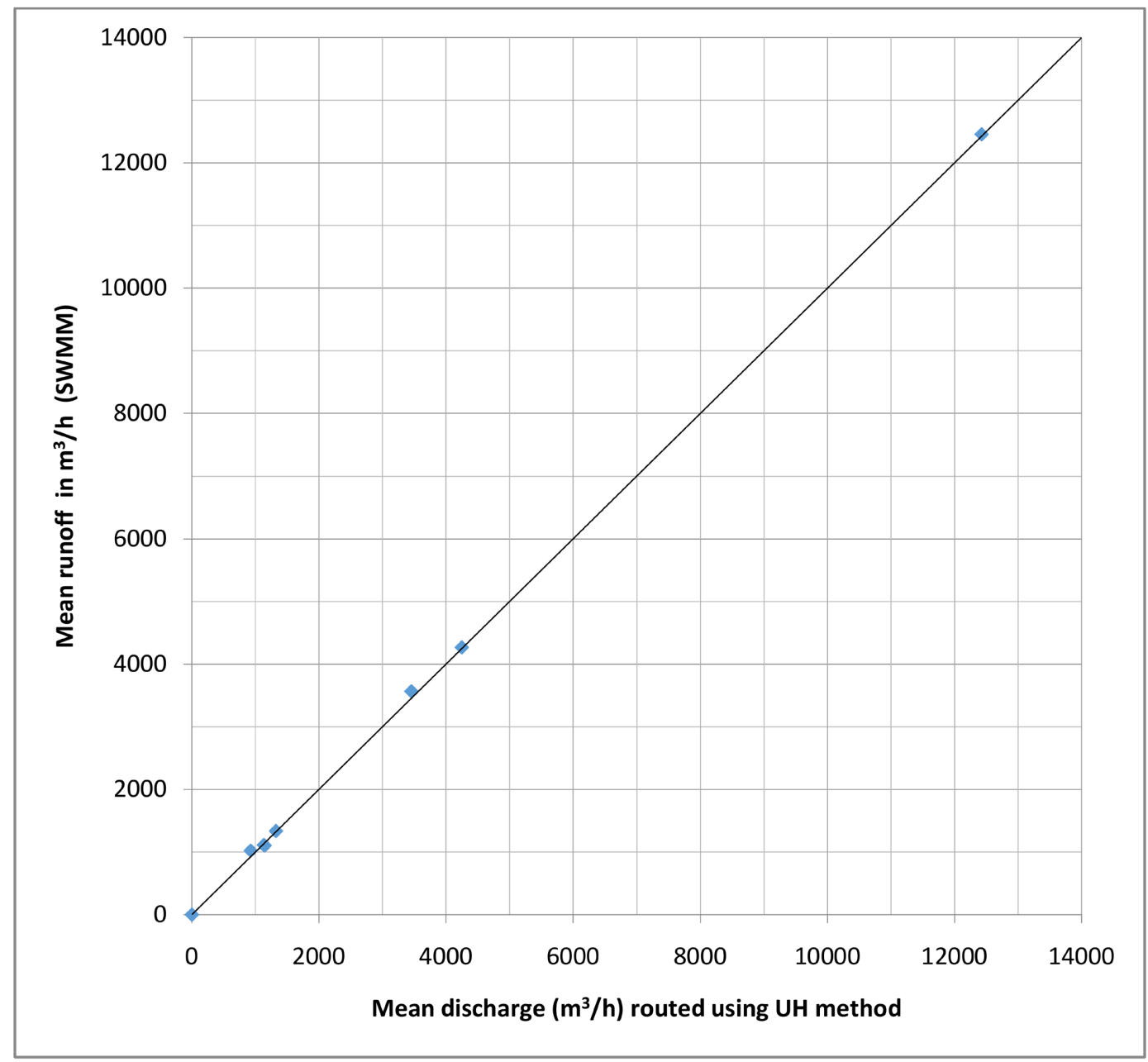

Figure 8. Simulated runoff from SWMM and mean of observed runoff from discretization using UH method for Event 1: 12 Jan 2016. 
the correlation coefficient is close to 0.9 where all the runoff values fall almost along the 45 degree line. The result of six sub-catchments, it can be said that existing drainage system is adequate for existing conditions. However, the runoff will change for critical storms other than the ones used in the current simulation events used in model calibration and verification. Comparison between mean simulated runoff and observed runoff from discretization using for various subcatchments of the same event is also shown in Figure 9.

This study can be used as a basis for infiltration and inflow (I/I) reduction analysis in urban sewerage systems. The study highlights on need for collection system configuration, flow monitoring data, and a review of system management practices to reduce excess storm runoff. In separate sanitary sewerage systems where pump stations are involved for intermediate lifting in sewer networks, there is also a need for efficient management of emergency ponds that are used to relieve flow from pump stations, which are also affected by excess storm runoff volumes.

Data as part of flow monitoring plan was used to assess total wet weather flow to the City's wastewater treatment plant from individual basins and to quantify infiltration and inflow (I/I), while calibration of SWMM model was undertaken to evaluate if the model can be used for prediction of storm runoff/total wet weather flows from extreme rainfall storm events in the area. Subsequently, this approach can be used to evaluate various management practices of reducing excess runoff in storm drainage systems as well as planning for infiltration and

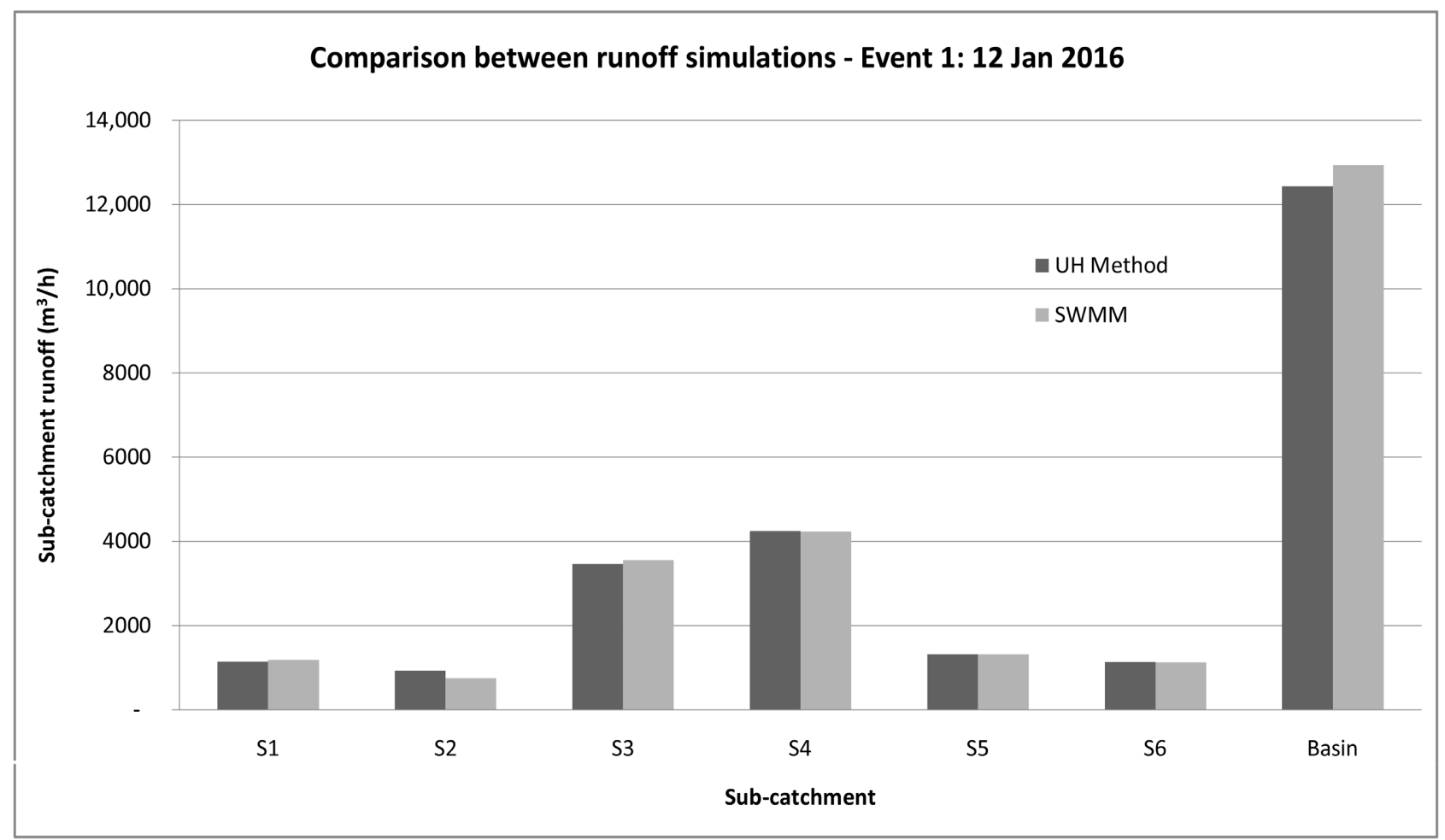

Figure 9. Comparison between mean simulated runoff and observed runoff from discretization using for various sub-catchments of Event 1:12 Jan 2016. 
inflow (I/I) reduction in sewer systems to alleviate excessive flows to wastewater treatment facilities in urban collection systems.

The calibrated SWMM model can be considered to evaluate predicted storm runoff/ total wet weather flows from extreme rainfall storm events in the study area, while the available data as part of flow monitoring plan can be used to further assess wet weather flow to the City's wastewater treatment plant from individual basins and to quantify infiltration and inflow (I/I). Subsequently, this approach can be used to evaluate various management practices of reducing excess runoff in storm drainage systems as well as infiltration and inflow (I/I) reduction in sewer systems to alleviate excessive flows to wastewater treatment facilities [35].

Various excess storm runoff reductions in urban areas using infrastructural and nature based solutions are required to achieve sustainability in the sustainable water management and effective risk mitigation for urban settlements as discussed in [3]. Low impact development (LID) as a new conception was proposed in order to solve urban stormwater problem since the 1990s [36]. LID measures are also used as a means to control runoff from the source through infiltration, filtration, evapotranspiration and other natural hydrological processes, aiming to the reduction of runoff quantity and pollution, and the protection of the receiving water, which is different from traditional stormwater management [7].

As part of urban planning and development concept, the concept of LID has been developed to include the concept of Sponge city e.g. [7] [37]. Other concepts have also evolved such as Sustainable Urban Water Management (SUWM) [38]; Water Sensitivity Urban Design (WSUD) [39]; Sustainable Urban Drainage System (SUDS) [40] [41] and urban storm water quality and sediment management [42].

\section{Acknowledgements}

The authors wish to appreciate the support of the University of Botswana and Department of Metrological Services, Water Utilities Corporation and Department of Water Affairs of the Botswana Government for encouraging this research directly or indirectly by providing the necessary information and support.

\section{Conflicts of Interest}

The authors declare no conflicts of interest regarding the publication of this paper.

\section{References}

[1] Zhang, C., Wang, Y. and Ding, W. (2017) Vulnerability Analysis of Urban Drainage Systems: Tree vs. Loop Networks. Jour nal of Sustainability, 9, Article No. 397. https://doi.org/10.3390/su9030397

[2] Dietz, M.E. (2007) Low Impact Development Practices: A Review of Current Re- 
search and Recommendations for Future Directions. Water, Air, and Soil Pollution, 186, 351-363. https://doi.org/10.1007/s11270-007-9484-Z

[3] Alemaw, B.F., Chaoka, T. and Tafesse, N. (2020) Modelling of Nature-Based Solutions (NBS) for Urban Water Management-Investment and Outscaling Implications at Basin and Regional Levels. Journal of Water Resource and Protection, 12, 853-883. https://doi.org/10.4236/jwarp.2020.1210050

[4] Yazdanfar, Z. and Sharma, A.K. (2015) Urban Drainage System Planning and Design-Challenges with Climate Change and Urbanization: A Review. Water Science and Technology, 72, 165-179. https://doi.org/10.2166/wst.2015.207

[5] Beeneken, T., Erbe, V., Messmer, A., Reder, C., Rohlfing, R., Scheer, M., Schuetze, M., Schumacher, B., Weilandt, M. and Weyand, M. (2013) Real Time Control (RTC) of Urban Drainage Systems-A Discussion of the Additional Efforts Compared to Conventionally Operated Systems. Urban Water Journal, 10, 293-299. https://doi.org/10.1080/1573062X.2013.790980

[6] Willems, P., Arnbjerg-Nielsen, K., Olsson, J. and Nguyen, V.T.V. (2012) Climate Change Impact Assessment on Urban Rainfall Extremes and Urban Drainage: Methods and Shortcomings. Atmospheric Research, 103, 106-118.

https://doi.org/10.1016/j.atmosres.2011.04.003

[7] Shafique, M. and Kim, R. (2017) Retrofitting the Low Impact Development Practices into Developed Urban Areas Including Barriers and Potential Solution. Open Geosciences, 9, 240-254. https://doi.org/10.1515/geo-2017-0020

[8] André, L.L.S. (2016) Cumulative Equations for Continuous Time Chicago Hyetograph Method. Brazilian Jour nal of Water Resources, 21, 646-651.

https://doi.org/10.1590/2318-0331.011615094

[9] Moriasi, D.N., Arnold, J.G., Van Liew, M.W., Bingner, R.L., Harmel, R.D. and Veith, T.L. (2007) Model Evaluation Guidelines for Systematic Quantification of Accuracy in Watershed Simulations. Transactions of the ASABE (American Society of Agricultural and Biological Engineers), 50, 885-900.

https://doi.org/10.13031/2013.23153

[10] Zaghloul, N.A. (1983) Discussion of "SWMM Model and Level of Discretization" by Nabil A. Zaghloul (November, 1981). Jour nal of Hydraulic Engineering, 109, 17731776. https://doi.org/10.1061/(ASCE)0733-9429(1983)109:12(1773)

[11] Williams, K.K. (1980) Calibration of Federal Agency Storm Water Runoff Quantity Models for Oklahoma City. Department of Civil Engineering and Environmental Science, University of Oklahoma. Proceedings of Oklahoma Academy of Sciences, 60, 75-81.

[12] Patil, V.S., Patil, N.S., Vijaykumar, H. and Nanjundi, P. (2015) Design of Drainage Network Using SWMM for VTU Campus Belagavi. International Journal of Applied Environmental Sciences, 10, 1485-1491.

[13] Cambez, M.J., Pinho, J. and David, L.M. (2008) Using SWMM 5 in the Continuous Modelling of Stormwater Hydraulics and Quality. 11 th Inter national Confer ence on Urban Drainage, Edinburgh, 31 August-5 September 2008, 1-10.

[14] Elliott, A.H. and Trowsdale, S.A. (2007) A Review of Models for Low Impact Urban Stormwater Drainage. Environmental Modelling Software, 22, 394-405. https://doi.org/10.1016/j.envsoft.2005.12.005

[15] Nasrin, T., Sharma, A.K. and Muttil, N. (2017) Impact of Short Duration Intense Rainfall Events on Sanitary Sewer Network Performance. Water, 9, Article No. 225. https://doi.org/10.3390/w9030225

[16] Zhang, Z. (2007) Estimating Rain Derived Inflow and infiltration for Rainfalls of 
Varying Characteristics. Journal of Hydraulic Engineer ing, 133, 98-105. https://doi.org/10.1061/(ASCE)0733-9429(2007)133:1(98)

[17] Yilmaz, A.G. and Perera, B.J.C. (2014) Extreme Rainfall Nonstationarity Investigation and Intensity-Frequency-Duration Relationship. Journal of Hydrologic Engineering, 19, 1160-1172. https://doi.org/10.1061/(ASCE)HE.1943-5584.0000878

[18] Alemaw, B.F. and Sebusang, N.M. (2019) Climate Change and Adaptation-Induced Engineering Design and Innovations in Water Development Projects in Africa. Afr $i$ can Jour nal of Science, Technology, Innovation and Development, 11, 197-209. https://doi.org/10.1080/20421338.2017.1355601

[19] Zhou, Q. (2014) A Review of Sustainable Urban Drainage Systems Considering the Climate Change and Urbanization Impacts. Water, 6, 976-992.

https://doi.org/10.3390/w6040976

[20] Blecken, G.T., Hunt, W.F., Al-Rubaei, A.M., Viklander, M. and Lord, W.G. (2015) Stormwater Control Measure (SCM) Maintenance Considerations to Ensure Designed Functionality. Urban Water Journal, 14, 278-290. https://doi.org/10.1080/1573062X.2015.1111913

[21] Fryd, O., Dam, T. and Jensen, M.B. (2012) A Planning Framework for Sustainable Urban Drainage Systems. Water Policy, 14, 865-886.

https://doi.org/10.2166/wp.2012.025

[22] Astaraie-Imani, M., Kapelan, Z., Fu, G. and Butler, D. (2012) Assessing the Combined Effects of Urbanisation and Climate Change on the River Water Quality in an Integrated Urban Wastewater System in the UK. Journal of Environmental Management, 112, 1-9. https://doi.org/10.1016/j.jenvman.2012.06.039

[23] Piyumi, M.M.M., Abenayake, C., Jayasinghe, A. and Wijegunarathna, E. (2021) Urban Flood Modeling Application: Assess the Effectiveness of Building Regulation in Coping with Urban Flooding Under Precipitation Uncertainty. Sustainable Cities and Society, 75, Article ID: 103294. https://doi.org/10.1016/j.scs.2021.103294

[24] Arnbjerg-Nielsen, K. and Fleischer, H.S. (2009) Feasible Adaptation Strategies for Increased Risk of Flooding in Cities Due to Climate Change. Water Science and Technology, 60, 273-281. https://doi.org/10.2166/wst.2009.298

[25] Nie, L., Lindholm, O., Lindholm, G. and Syversen, E. (2009) Impacts of Climate Change on Urban Drainage Systems-A Case Study in Fredrikstad, Norway. Urban Water Journal, 6, 323-332. https://doi.org/10.1080/15730620802600924

[26] Bisht, D.S., Chatterjee, C., Kalakoti, S., Upadhyay, P., Sahoo, M. and Panda, A. (2016) Modeling Urban Floods and Drainage Using SWMM and MIKE URBAN: A Case Study. Natural Hazards, 84, 749-776.

https://doi.org/10.1007/s11069-016-2455-1

[27] Barco, J., Wong, K.M. and Stenstrom, M.K. (2008) Automatic Calibration of the U.S. EPA SWMM Model for a Large Urban Catchment. Journal of Hydraulic Engineering, 134, 466-474. https://doi.org/10.1061/(ASCE)0733-9429(2008)134:4(466)

[28] Choi, K.-S. and Ball, J.E. (2002) Parameter Estimation for Urban Runoff Modelling. Urban Water, 4, 31-41. https://doi.org/10.1016/S1462-0758(01)00072-3

[29] Leutnant, D., Döring, A. and Uhl, M (2019) Swmmr-An R Package to Interface SWMM. Urban Water Journal, 16, 68-76.

https://doi.org/10.1080/1573062X.2019.1611889

[30] Alemaw, B.F. and Chaoka, T.R. (2016) Regionalization of Rainfall Intensity-Duration-Frequency (IDF) Curves in Botswana. Journal of Water Resource and Protection, 8, 1128-1144. https://doi.org/10.4236/jwarp.2016.812088 
[31] Richards, L.A. (1931) Capillary Conduction of Liquids through Porous Mediums. Physics, 1, 318-333. https://doi.org/10.1063/1.1745010

[32] Nash, J.E. and Sutcliffe, J.V. (1970) River Flow Forecasting through Conceptual Models Part I-A Discussion of Principles. Jour nal of Hydrology, 10, 282-290. https://doi.org/10.1016/0022-1694(70)90255-6

[33] Chow, V.T. (1959) Open Channel Hydraulics. MrGraw-Hill Book Co., New York.

[34] Yen, B.C. (1992) Channel Flow Resistance: Centennial of Manning's Formula Water Resources Publications, LLC., Colorado, 460.

[35] Pawlowski, C.W., Rhea, L, Shuster, W.D. and Barden, G. (2013) Some Factors Affecting Inflow and Infiltration from Residential Sources in a Core Urban Area: Case Study in a Columbus, Ohio, Neighborhood. Journal of Hydraulic Engineering, 140, 105-114. https://doi.org/10.1061/(ASCE)HY.1943-7900.0000799

[36] Cheng, M.S., Coffman, L., Riverson, J., Shen, J., Ouyang, J., Lahlou, M. and Shoemaker, L. (2002) Low-Impact Development Management Practices Evaluation Computer Module. Jour nal of WEFTEC, 2002, 1522-1534.

[37] Yu, K.J. and Li, D.H. (2015) Sponge City Theory and Practice. Journal of CCPR, 39, 26-36

[38] David, R.M., Magnus, M., Stephen, C. and David, J.B. (2013) Towards Sustainable Urban Water Management: A Critical Reassessment. Water Resources, 47, 7150-7161. https://doi.org/10.1016/j.watres.2013.07.046

[39] Wong, T.H.F. (2006) Water Sensitive Urban Design-The Journey Thus Far. Australasian Journal of Water Resources, 10, 213-222. https://doi.org/10.1080/13241583.2006.11465296

[40] Davis, M.K. and Naumann, S. (2017) Chapter 8. Making the Case for Sustainable Urban Drainage Systems as a Nature-Based Solution to Urban Flooding. In: Kabisch, N., Korn, H., Stadler, J. and Bonn, A., Eds., Nature-Based Solutions to Climate Change Adaptation in Urban Areas, Theory and Practice of Urban Sustainability Transitions, Springer, Cham, 123-137. https://doi.org/10.1007/978-3-319-56091-5_8

[41] Nordeidet, B., Nordeide, T., Asteb $\Phi$ l, S.O. and Hvitved, J.T. (2004) Prioritising and Planning of Urban Stormwater Treatment in the Alna Watercourse in Oslo. Science of the Total Environment, 334-335, 231-238.

https://doi.org/10.1016/j.scitotenv.2004.04.040

[42] Drapeau, C., Delolme, C., Chatain, V., Gautier, M., Blanc, D., Benzaazoua, M. and Lassabatère, L. (2017) Spatial and Temporal Stability of Major and Trace Element Leaching in Urban Stormwater Sediments. Open Journal of Soil Science, 7, 347-365. https://doi.org/10.4236/ojss.2017.711025 